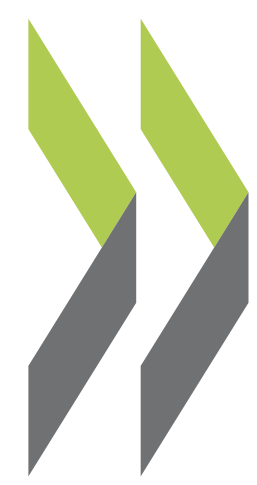

OECD Economics Department Working Papers No. 338

Coping with Population

Andrew Burns, Ageing in Hungary Jaromir Cekota 
Organisation de Coopération et de Développement Economiques

Organisation for Economic Co-operation and Development

14-Aug-2002

ECONOMICS DEPARTMENT

English text only

COPING WITH POPULATION AGEING IN HUNGARY

ECONOMICS DEPARTMENT WORKING PAPERS NO.338

by

Andrew Burns and Jaromir Cekota

All Economics Department Working Papers are now available through OECD's Internet Web site at http://www.oecd.org.eco 


\section{ABSTRACT/RÉSUMÉ \\ COPING WITH POPULATION AGEING IN HUNGARY}

This paper examines economic challenges posed by the combination of an ageing and declining population in Hungary and develops policy-oriented recommendations for addressing them. The authors identify the scale and specific properties of the demographic problem in Hungary where the population started to decline earlier than in any other OECD country. Public support for the elderly is provided by the social-security pension system and the healthcare system. While the former was reformed with partial success in the late 1990s, the latter developed less successfully, threatening to generate massive deficits in the long run. Projections indicate that even the public pension system may become unsustainable, unless the authorities restore the parameters of the original reform and encourage successfully higher labour force participation. In this context, measures to improve employability of the numerically strong and growing Roma minority are particularly pertinent. The healthcare sector needs to be reformed radically for its efficiency to be appreciably enhanced; such reform should be complemented by an increased scope for private provision and financing of health services.

JEL classification: I1, I3, J1, J11, J14, J26

Keywords: Hungary, population ageing, pension, health care, long-term projections

$* * * * *$

\section{LE PROBLÈME DU VIEILLISSEMENT DÉMOGRAPHIQUE EN HONGRIE}

Le présent document examine les problèmes économiques posés par la conjonction du vieillissement et de la diminution de la population hongroise et propose des recommandations d'action pour y remédier. Les auteurs analysent l'ampleur et les caractéristiques du problème démographique en Hongrie, où la population a commencé à se réduire plus tôt que dans les autres pays de l'OCDE. Les personnes âgées bénéficient d'aides de l'Etat par le biais du système d'assurance sociale au titre des pensions et du système de santé. Si le premier a été réformé avec un certain succès à la fin des années 90 , l'évolution du second est plus préoccupante et risque de se traduire par de très importants déficits à long terme. Si l'on en juge d'après les prévisions, le système public de pensions pourrait lui-même ne pas être tenable en longue période, à moins que les autorités ne modifient les paramètres de la réforme initiale et n'obtiennent une élévation du taux d'activité. Dans ce contexte, des mesures visant à améliorer l'employabilité de la minorité tzigane, déjà nombreuse et en forte croissance, sont particulièrement judicieuses. Le secteur de la santé doit faire l'objet d'une réforme radicale si l'on veut en améliorer sensiblement l'efficience; il faudrait, parallèlement à cette réforme, faire une plus large place à la fourniture et au financement privés de services de santé.

JEL classification: I1, I3, J1, J11, J14, J26

Keywords: Hongrie, vieillissement démographique, pensions, services de santé, prévisions à long terme

\section{Copyright OECD 2002}

Applications for permission to reproduce or translate all, or part of, this document should be made to Head of Publications Service, OECD, 2 rue André Pascal, 75775 PARIS CEDEX 16, France. 


\section{TABLE OF CONTENTS}

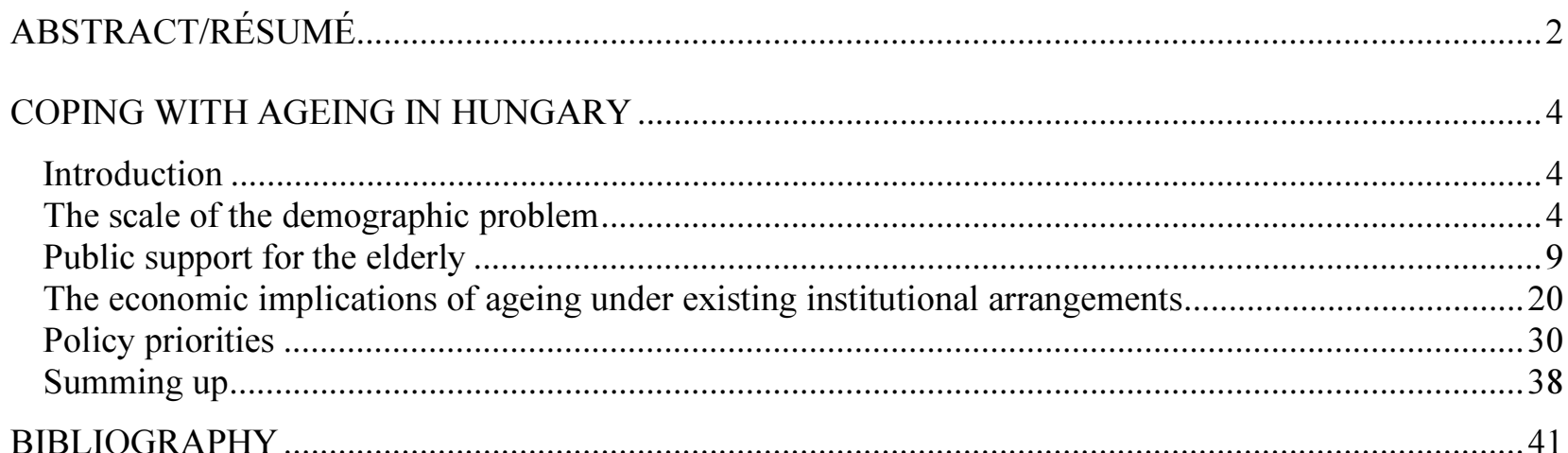

\section{Tables}

1. Fertility and life expectancy

2. Participation in mandatory private pension funds

3. Growth rates of employment, productivity and GDP

4. Membership and assets of Hungarian pension funds

\section{Figures}

1. Population scenarios

2. Demography and employment

3. Employment/population ratios for men and women

4. Pension benefit recipients by type of benefit

5. Dependency ratios

6. Demand for health services

7. Social security deficit: sensitivity to employment and productivity growth

8. Social security deficit: sensitivity to demographic assumptions

9. $\quad$ PAYG balance with lower contribution rates

10. The evolution of healthcare supply

11. Sensitivity of the PAYG balance to revenue-enhancing reforms

\section{Boxes}

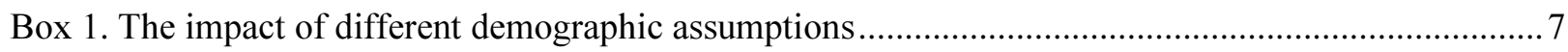

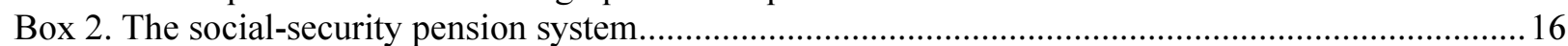

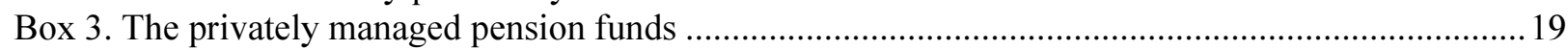

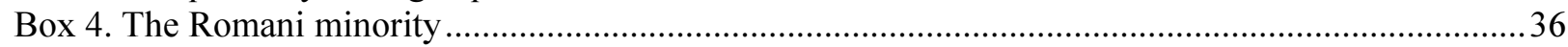

Box 5. Increasing prosperity in an ageing society: an overview of recommendations.............................39 


\title{
COPING WITH AGEING IN HUNGARY
}

\author{
by Andrew Burns and Jaromir Cekota ${ }^{1}$
}

\section{Introduction}

1. As will be the case in many OECD countries, the ageing of Hungary's population over the next several decades will pose major economic and societal challenges. Even assuming an increase in immigration and significant improvement in fertility rates and life expectancy, Hungary's current population of 10 million will fall by as much as 20 per cent over the next 50 years. Moreover, the proportion of persons 65 or older will more than double while the working-age population shrinks. This paper begins by examining the demographics of the ageing population and its sensitivity to changes in hypotheses concerning fertility, life expectancy and immigration. It then briefly reviews the existing institutional support for the elderly. This is followed by an examination of the macroeconomic, financial and social implications of these changes with a special emphasis on the financial sustainability of Hungary's elderly support systems. The paper concludes by suggesting some concrete steps that policy makers can take now to meet these challenges.

\section{The scale of the demographic problem}

2. Nearly all OECD countries are expected to see their populations age over the next fifty years and the populations of a number of them are projected to decline. Such is the case in Hungary, where a rapid drop in fertility below the rate necessary to sustain a steady population (approximately 2.1 live births per woman) and high mortality rates caused the population to start declining in 1980, earlier than in any other OECD country. As elsewhere, the drop in birth rates was caused by behavioural and social changes made possible by more effective and easily accessible contraception and was reflected in lower marriage rates; increased rates of divorce and non-marital cohabitation and the postponement of parenthood. ${ }^{2}$ Indeed, this

1. An earlier version of this paper served appeared as a special chapter in the OECD Economic Survey of Hungary, which was published in November 2000 under the authority of the Economic and Development Review Committee of the OECD. Andrew Burns is the head of the France/Poland desk while Jaromir Cekota is an economist at the Czech Republic/Hungary desk in the OECD Economics Department. The authors are indebted to Val Koromzay, Andrew Dean, Jean-Claude Chouraqui and Andreas Wörgötter for valuable comments on earlier drafts. József Mészaros (Director General of the Hungarian Pension Administration) helped us patiently to understand the functioning of the public pension system. László Hablicsek (Director of the Demographic Institute of the Hungarian Statistical Office) provided us with essential demographic projections. János Stahl (Chief Actuary of the Hungarian Pension Supervision) supervised pension model simulations requested by the authors. Special thanks go to Margaret Morgan for statistical support, and to Diane Scott for secretarial assistance.

2. For a detailed survey of fertility patterns in Hungary, see Kamaras (1999). 
process has advanced so far that Hungary now has the sixth lowest aggregate fertility rate among member countries (see Table 1). Meanwhile, short life expectancy (life expectancy failed to keep pace with western levels in the 1960s and for older males actually declined in absolute terms during the 1980s) accelerated the impact of these changes on the aggregate population. ${ }^{3}$ While the precise reasons for such poor health outcomes are unknown (see the previous Survey for a more complete discussion), high incidences of alcoholism and smoking, a fat-rich diet and a sedentary lifestyle coupled with poor economic prospects are frequently presented as causes. Looking forward and even assuming an improvement on these fronts, the ageing and shrinking of the population is expected to continue and the drop in Hungary's population over the next 50 years is projected to be the second largest in the OECD (in relative terms). At the same time, high mortality rates mean that the number of people over 65 years of age will rise by only 40 per cent as compared with an OECD average increase of more than 100 per cent.

3. The three panels of Figure 1 illustrate several dimensions of Hungary's population over the next 50 years. Depending upon the speed with which life expectancy and fertility rise and the extent of immigration (Box 1), Hungary's population is projected to fall by between 15 and 25 per cent (Figure 1, Panel A). At the same time, the overall dependency rate (the number of people less than 20 and older than 65 years divided by the number between those two ages) is expected to rise from its current 63 per cent to somewhere between 77 and 96 per cent, which compares favourably with a projected OECD average of 91 per cent in 2050. Panel C, provides a summary view of these demographic developments. Already in 2000 the influence of reduced fertility can be seen in an undercutting of the pyramid shape that typically characterises the age profile of a growing or stationary population. By 2050, despite an assumed improvement in fertility, this undercutting process is well advanced and the distribution has become noticeably "top heavy", with older cohorts almost always larger than younger ones — an age profile consistent with a shrinking population.

4. In Panel A of Figure 2, the evolution of the overall population that is presented in Figure 1 is traced along with the working-age population that is consistent with it. The increasing share of persons over 65 in the population means that after 2010 the working-age cohort tends to fall even more quickly than the population as a whole. As concerns employment, its path depends on the size and employment rates of the various age-sex cohorts that make up the working-age population. Currently, employment rates in Hungary for all age-sex groups are among the lowest in the OECD, but this is especially true for older workers (Figure 3$)^{4}$ and the minority Romani population. If age-sex specific employment rates remain unchanged, employment can be expected to fall by more than 25 per cent over the next 50 years (the thick dashed line in the upper panel of Figure 2), in part because, as the share of older workers rises, the aggregate employment rate will decline (Figure 2, Panel B). Fortunately, labour market performance over the past several years has been improving and the overall strength of the economy suggest that it should continue to do so. In addition, as the minimum age of retirement rises and early-retirement programmes expire in line with policies already in place, the employment rates of older workers should rise. ${ }^{5}$ On the other hand, rising enrolment rates and longer periods of schooling suggest that the employment rates of

3. The population's shorter life expectancy implies that the demographic impact of a given change in fertility rates feeds into aggregate population statistics more quickly.

4. For people between 55 and 64, non-employment is endemic with employment rates for men and women of 29.7 and 11.3 per cent respectively, substantially below the OECD averages of 60.8 and 37.6 per cent.

5. Statutory retirement ages for men and women are being raised from their 1997 levels of 60 and 55 years respectively to 62 years of age by 2000 and 2009 respectively. 
Table 1. Fertility and life expectancy ${ }^{1}$

Five-year averages

\begin{tabular}{|c|c|c|c|c|c|c|c|c|c|c|}
\hline & \multicolumn{5}{|c|}{ A. Total fertility rates } & \multicolumn{5}{|c|}{ B. Life expectancy at birth } \\
\hline & \multicolumn{5}{|c|}{ Number of live born children per woman ${ }^{2}$} & \multicolumn{5}{|c|}{ Men and women } \\
\hline & $1950-55$ & $1970-75$ & $1995-2000$ & $2020-25$ & $2045-50$ & $1950-55$ & $1970-75$ & $\begin{array}{l}1995- \\
2000\end{array}$ & $2020-25$ & $2045-50$ \\
\hline Hungary & 2.7 & 2.1 & 1.4 & 1.5 & 1.7 & 63.6 & 69.3 & 70.9 & 75.1 & 78.7 \\
\hline Australia $^{3}$ & 3.2 & 2.5 & 1.8 & 1.9 & 1.9 & 69.6 & 71.7 & 78.3 & 80.7 & 82.7 \\
\hline Austria & 2.1 & 2.0 & 1.4 & 1.7 & 1.7 & 65.7 & 70.6 & 77.0 & 79.7 & 81.7 \\
\hline Belgium & 2.3 & 1.9 & 1.6 & 1.8 & 1.9 & 67.5 & 71.4 & 77.2 & 79.9 & 82.0 \\
\hline Canada & 3.7 & 2.0 & 1.6 & 1.9 & 1.9 & 69.1 & 73.2 & 79.0 & 81.2 & 83.2 \\
\hline Czech Republic & 2.7 & 2.2 & 1.2 & 1.4 & 1.7 & 67.5 & 70.0 & 73.9 & 79.0 & 81.2 \\
\hline Denmark & 2.5 & 2.0 & 1.7 & 1.9 & 1.9 & 71.0 & 73.6 & 75.7 & 78.1 & 80.5 \\
\hline Finland & 3.0 & 1.6 & 1.7 & 1.9 & 1.9 & 66.3 & 70.7 & 76.8 & 80.8 & 82.7 \\
\hline France & 2.7 & 2.3 & 1.7 & 2.0 & 2.0 & 66.5 & 72.4 & 78.1 & 80.6 & 82.6 \\
\hline Germany & 2.2 & 1.6 & 1.3 & 1.6 & 1.6 & 67.5 & 71.0 & 77.2 & 79.8 & 81.9 \\
\hline Greece & 2.3 & 2.3 & 1.3 & 1.5 & 1.8 & 65.9 & 72.3 & 78.1 & 80.5 & 82.5 \\
\hline Iceland & 3.7 & 2.8 & 2.1 & 1.9 & 1.9 & 72.0 & 74.3 & 79.0 & 81.4 & 83.4 \\
\hline Ireland & 3.4 & 3.8 & 1.9 & 2.1 & 2.1 & 66.9 & 71.3 & 76.4 & 80.6 & 82.6 \\
\hline Italy & 2.3 & 2.3 & 1.2 & 1.5 & 1.7 & 66.0 & 72.1 & 78.2 & 80.7 & 82.6 \\
\hline Japan & 2.7 & 2.1 & 1.4 & 1.7 & 1.8 & 63.9 & 73.3 & 80.0 & 81.9 & 83.8 \\
\hline Korea & 5.4 & 4.3 & 1.7 & 1.9 & 1.9 & 47.5 & 62.6 & 72.4 & 77.1 & 79.9 \\
\hline Luxembourg & 2.0 & 2.0 & 1.7 & 1.8 & 1.8 & 65.9 & 70.7 & 76.7 & 79.7 & 81.8 \\
\hline Mexico & 6.9 & 6.5 & 2.8 & 2.1 & 2.1 & 50.6 & 62.4 & 72.2 & 76.1 & 78.8 \\
\hline Netherlands & 3.1 & 2.0 & 1.5 & 1.7 & 1.9 & 72.1 & 74.0 & 77.9 & 80.3 & 82.3 \\
\hline New Zealand & 3.6 & 2.8 & 2.0 & 2.1 & 2.1 & 69.6 & 71.7 & 76.9 & 79.9 & 81.9 \\
\hline Norway & 2.6 & 2.2 & 1.9 & 2.0 & 2.0 & 72.7 & 74.4 & 78.1 & 81.2 & 83.7 \\
\hline Poland & 3.6 & 2.2 & 1.5 & 1.7 & 1.9 & 61.3 & 70.5 & 72.5 & 77.2 & 79.9 \\
\hline Portugal & 3.0 & 2.7 & 1.4 & 1.6 & 1.8 & 59.3 & 68.0 & 75.3 & 78.9 & 81.1 \\
\hline Spain & 2.6 & 2.9 & 1.2 & 1.4 & 1.7 & 63.9 & 72.9 & 78.0 & 80.5 & 82.5 \\
\hline Sweden & 2.2 & 1.9 & 1.6 & 1.8 & 2.0 & 71.8 & 74.7 & 78.6 & 81.6 & 83.6 \\
\hline Switzerland & 2.3 & 1.8 & 1.5 & 1.7 & 1.7 & 69.2 & 73.8 & 78.7 & 80.9 & 82.9 \\
\hline Turkey & 6.8 & 5.0 & 2.5 & 2.1 & 2.1 & 43.6 & 57.9 & 69.0 & 74.9 & 78.6 \\
\hline United Kingdom & 2.2 & 2.0 & 1.7 & 1.9 & 1.9 & 69.2 & 72.0 & 77.2 & 80.0 & 82.0 \\
\hline United States & 3.4 & 2.0 & 2.0 & 1.9 & 1.9 & 69.0 & 71.3 & 76.7 & 79.7 & 81.8 \\
\hline $\mathrm{OECD}^{4}$ & $\begin{array}{l}0.4 \\
3.1\end{array}$ & 2.6 & 1.7 & 1.8 & 1.9 & 65.3 & 70.8 & 76.4 & 79.6 & 81.8 \\
\hline
\end{tabular}

1. Estimates to 1995 , projections from 2000 , medium fertility variant, for five year period to date shown.

2. Throughout the child bearing period, based on age-specific fertility rates in the given year.

3. Including Christmas Island, Cocos (Keeling) Islands and Norfolk Island.

4. Unweighted average.

Source: United Nations Population Division, World Population Prospects: The 1998 Revision. 
ECO/WKP(2002)24

\section{Box 1. The impact of different demographic assumptions}

The demographic projections used in this chapter for the time period 2000-50 exhibit strong sensitivity to the underlying assumptions about fertility, longevity and net migration. Two sets of projections are employed. The first, produced by the United Nations Populations Division (UN), is utilised for demographic comparisons of Hungary with other OECD countries. The second set of projections, produced by the Demographic Institute of the Central Statistical Office of Hungary (DICSO), provides the basis for discussion in the sections dealing with the economic implications of the changes in the structure of population.

\section{Baseline scenarios}

The UN baseline scenario assumes net migration of zero and slowly rising fertility and longevity (Table 1). The main DICSO scenario assumes a permanent increase in annual net immigration from zero to 4000 persons in 2001 as well as a slowly rising fertility rate from 1.3 in 2000 to 1.6 in 2030 after which it stays constant. The improvements in life expectancy in the two scenarios are very similar, resulting in almost identical values for both genders in the year 2050 (75 and 82 years for men and women respectively). The population size predicted by the DICSO model is consistently higher than the UN projection with the difference in the projected population rising from 50000 persons in 2010 to 548500 in 2050. The number of people aged 65 and over is practically identical in 2050 in each projection.

\section{Alternative scenarios}

The secretariat was provided with two alternative DICSO scenarios. The so-called "old variant" assumes, relative to the baseline scenario, lower fertility ( 1.3 by 2050), higher life expectancy ( 83 and 87 years for men and women by 2050) and net out-migration of 4000 persons per annum starting in 2001. In contrast, the "young variant" assumes higher fertility (1.9 by 2050), lower life expectancy (67/77 years for men/women by 2050) and net immigration of 12000 persons per annum beginning in 2001. The differences in the final outcomes are striking. The "old variant" predicts for the year 2050 a population of 7.4 million, including 2.6 million persons aged 65 or more while the "young variant" projects a population of 8.8 million, including 1.7 million persons in the $65+$ age group and older.

\section{The ethnic composition of population}

In addition to the scenarios for total population and its age composition, a methodologically consistent demographic model for the Romani population in Hungary was developed at the DICSO and is presented in Hablicsek (1999). As with the main DICSO model, there are three versions based on slightly different assumptions about fertility and longevity patterns. The baseline ethnic model predicts that the population of Roma will almost double (increasing from 609000 in 2000 to 1.2 million in 2050). Ageing in the Romani population will be more extreme with the 65+ age group increasing six-fold (from 19000 to 128000 persons), although the overall dependency ratio for this group will decline from 97 to 72 per cent. The prime working age (20-64 years) Romani population is projected to grow from 310000 persons in 2000 to 684000 in 2050 . 
Figure 1. Population scenarios
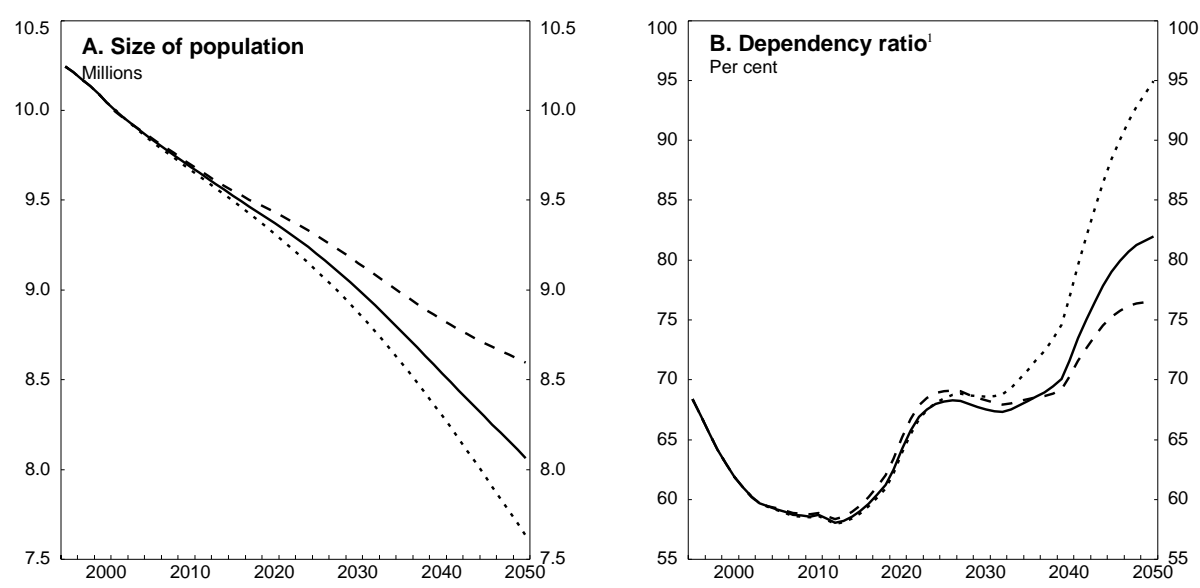

- - - Young - low life expectancy, high fertility, high net migration

- Medium/REFERENCE - medium life expectancy, medium fertility, medium net migration

..... Old - high life expectancy, low fertility, low net migration

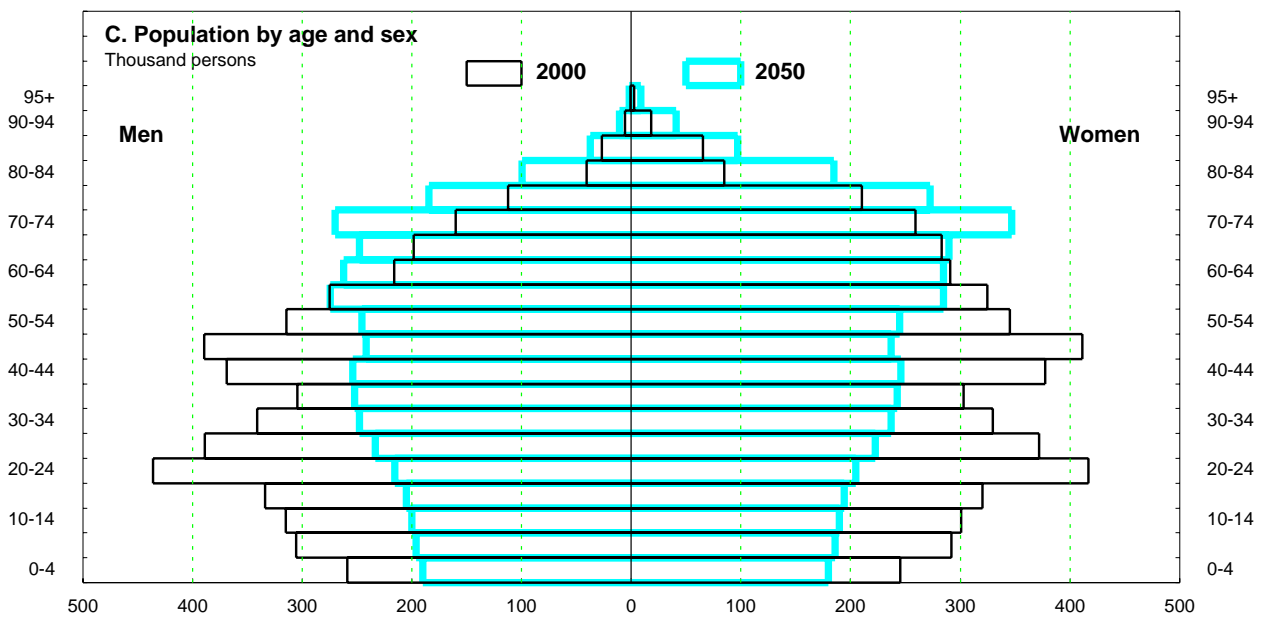

1. Population aged 0-19 and 65 and over divided by population aged 20-64 Source: Demographic Institute of the Central Statistical Office. 
younger Hungarians will fall over time. The thin dotted line in both panels of Figure 2 models these effects by assuming that age-specific employment rates converge to Austrian levels by 2010 and that afterwards female rates continue to rise until they reach 90 per cent of male rates. Moreover, it assumes that Roma participation rates converge rapidly to simulated national averages, resulting by 2050 in an employment gain of 240000 persons. On this basis, the aggregate employment rate (15-64) will rise to 66 per cent by 2050 (well above the current OECD average) and although employment levels still fall, the decline is reduced to 600000 persons ( 20 per cent of its 2000 level). Most importantly, independent of which assumptions concerning the employment rate one chooses, employment will be falling for much of the next 50 years and the rate of decline accelerates after 2015 as the number of new entrants in line with today's much lower fertility rates.

\section{Public support for the elderly}

5. Given these demographic trends, demands for services for older citizens will inevitably grow. In contrast to other OECD economies, when they were at a similar level of development, Hungary already has a comprehensive support network for the elderly, comprised of the public healthcare system, various social assistance programmes targeted at the special needs of older individuals and a newly reformed compulsory public pension system. ${ }^{6}$ The paragraphs that follow describe, briefly, the salient characteristics of each of these systems in turn.

\section{The healthcare system for the aged}

6. The healthcare system was described in detail in the 1999 OECD Economic Survey of Hungary and progress towards reforming it and further suggestions for change were outlined in the preceding chapter of this year's review. While the healthcare system putatively operates on an insurance basis, in reality most services are provided free of charge irrespective of whether an individual has contributed to its financing and the system's substantial deficits are financed through transfers from the central budget (see OECD, 1999a). The health insurance system offers no special services for the elderly per se, although they benefit from free access to all health services as do all citizens. Moreover, drugs for the treatment of certain geriatric conditions are subsidised at high rates, reducing the user charge to a comparatively low amount or to zero in the case of low-income recipients. Overall, the public healthcare system spends some 6.6 per cent of GDP, with expenditures on older individuals accounting for 40 per cent of the total. ${ }^{7}$

7. As compared with some OECD countries, Hungary has a well-developed home healthcare and home social-assistance system. On the other hand, there is only 1 nursing-home bed for every thousand Hungarians (or 1 bed for every 140 individuals over the age of 65), less than half the number found in some OECD countries. While the need for more nursing homes is not disputed, officials believe that home care is much more extensive than in some OECD countries and that such services go a long way to filling this gap. ${ }^{8}$ Especially in rural areas General Practitioners (GPs) tend to spend as much as 4 hours of each day seeing patients (principally the elderly in their homes), with a significant part of these visits serving a social and mental health function. In addition, there is a system of home nursing care, which provides post-operative and pre-operative care as well as limited ongoing treatments. Nevertheless, the waiting lists

6. For an evaluation and description of the reform see OECD (1999a), Parniczky (2000), and Rocha and Vittas (2000).

7. Estimated from the elderly's share in in-patient healthcare expenditures.

8. Nevertheless, the authorities intend to restructure the distribution of beds within the health sector raising the share of nursing-home and chronic-care beds from 22 to more than 30 per cent of the total. 
and periods for placement in nursing homes have grown significantly and in 2000 unmet demand for nursing home places and in-patient geriatric care was twice as high as available capacity.

Figure 2. Demography and employment


1. Assumes that Hungarian age-sex participation rates rise to Austrian levels by 2010 and continue to improve afterwards as female

2. Assumes cohort-specific employment rates remain unchanged at their 1999 levels.
a

Source: OECD; Demographic Institute of the Central Statistical Office. 
ECO/WKP(2002)24

Figure 3. Employment/population ratios for men and women

1999
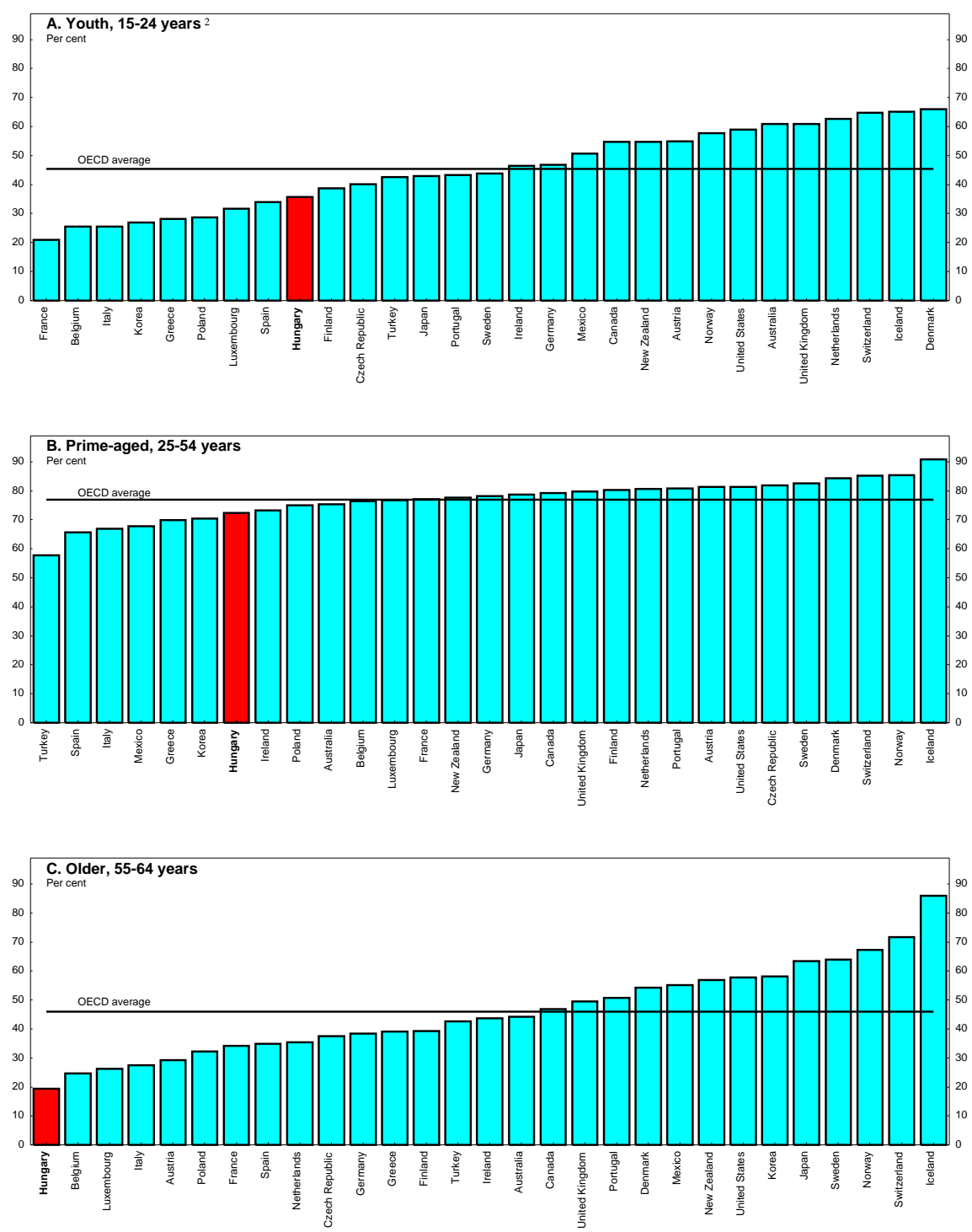

1. 1998 for Greece and Poland.

(6)-24 Ior Iceland, Norway, Spain, Sweden, United Kingdom and United States.

Source: OECD Employment Outlook 2000 
ECO/WKP(2002)24

\section{Social assistance for older persons}

8. While the pension system (see below) is the principal form of financial support provided to the elderly, it is complemented by a number of other benefits. In particular, since 1998 a means-tested old-age benefit is provided to destitute elderly persons. To qualify, claimants must be 62 years of age or older with an income below 80 per cent of the minimum old-age pension, which amounts to about one-half the average pension. ${ }^{9}$ Benefits are financed jointly by the central budget ( 75 per cent) and municipalities ( 25 per cent). If the recipient obtains any employment income, the old-age benefit is cut by a corresponding amount; implying an effective marginal tax rate on earned income of 100 per cent and a serious poverty trap. In 1999, only 10000 individuals received this benefit, although the number is expected to rise because much lower employment rates during the past decade mean that larger shares of each retiring cohort are likely to be ineligible for the standard pension and at the same time awareness of the benefit's existence will probably increase. ${ }^{10}$

9. After the old-age pensions, disability pensions are the second largest source of social-security income for the elderly, with some 325000 senior citizens currently relying upon them. In addition, these benefits, especially in the light-disability category, have been used as a mechanism for financing premature labour market withdrawal and as a substitute for unemployment insurance. Indeed, the fastest growing group of disability pensioners is workers between 46 and 60 years of age (see Figure 4 ) and the regional distribution of beneficiaries shows a strong correlation with unemployment rates. The authorities have tightened the approval procedures for light-disability claims since the beginning of 1998 and the number of new disability pensions granted has dropped significantly, although the number of working-age beneficiaries continues to rise.

10. Survivor benefits and a number of non-standard benefits and pensions are also provided. These include special retirement pensions (90 000 recipients), benefits for members of agricultural co-operatives (40 000 beneficiaries), non-standard disability and survivor benefits (160 000 recipients). Special pensions include early pensions (paid by the former employer until statutory retirement age), preliminary pensions (paid by the central government through its Labour Market Fund but since January 1998 no longer being offered) and miners' pensions (financed from the central budget). Recipients of the non-standard disability and survivor benefits include a high proportion of elderly citizens such as war widows and retired members of former co-operatives. In addition to cash benefits, the central government provides generous transportation subsidies to persons aged 65 or more years, entitling them to free travel on the state railways (MÁV) and inter-city bus service (VOLÁN).

11. Finally, in addition to the above-mentioned entitlements for seniors, a wide range of in-kind services such as in-home nursing, home social care, community-based social centres and subsidised home-delivered meals are provided by local governments on a discretionary basis and co-financed by the central budget. Other in-kind benefits provided by local government for the poor elderly include temporary housing, free local transport, a "village caretaker" programme that finances a local handyman who is available to elderly residents for small repairs, errands and limited taxi services, and benefits for the basic maintenance of dwellings. There are national standards regarding these benefits and, in general, municipalities do not spend more on welfare than the funds allocated for that purpose by the central government. Anecdotal evidence suggests that these benefits represent a strong work disincentive for

9. The minimum old-age pension amounts to 16600 forints per month (approximately \$60) for those who retire in 2000. If pensionable net earnings are less than this figure, the minimum pension is defined by the level of pensionable earnings.

10. Approximately 250000 persons of the working age receive regular and temporary welfare benefits; an unknown percentage of this group consists of persons who have effectively opted for this form of early retirement (the entitlement to welfare benefits is not time limited). 
low-income senior citizens as municipalities tend to cut them off as soon as a senior gains access to additional resources.

Figure 4. Pension benefit recipients by type of benefit

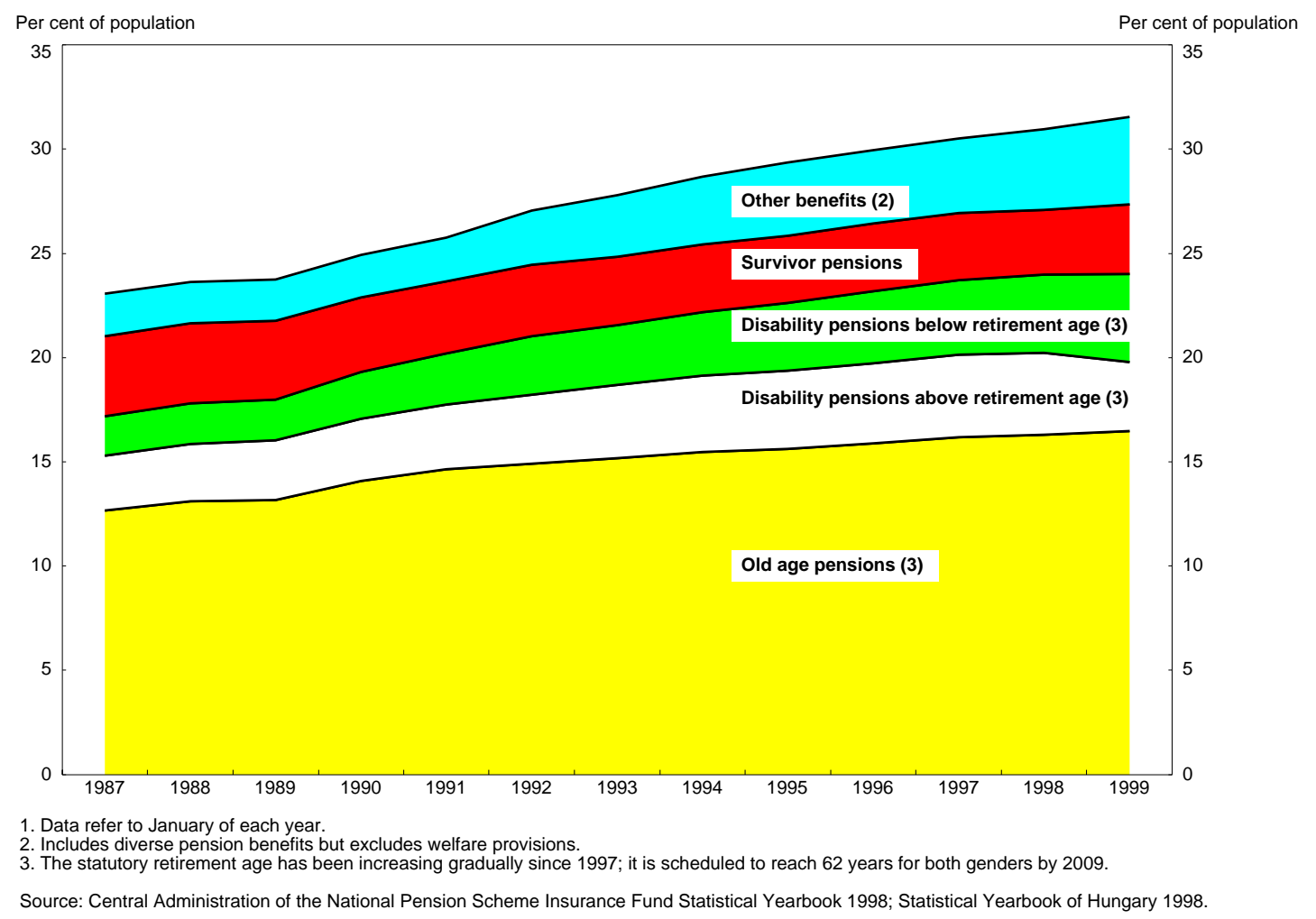

12. The support of the state and municipalities for elderly citizens is augmented by traditional support provided by family members. Especially in rural areas, many elderly parents live with their children and both they and grandchildren are legally obliged to take care of their older relatives, although this obligation does not appear to be widely enforced. For example, when considering whether an elderly person qualifies for the means-tested old-age benefit, the income and wealth situation of close relatives is not taken into account. However, if an older person needs to be placed in a nursing home, close relatives are obliged, under certain conditions, to share costs according to their means. ${ }^{11}$

13. The government recognises the importance of the ageing issue and the Ministry of Health and Ministry of Family and Social Affairs have set up an inter-ministerial committee to help co-ordinate their approaches to the problem. In an effort to foster a long-range strategic approach to the issue the Ministry of Health recently created an independent Health Improvement Research Agency (EFKI) to study ageing among other issues. In addition, it is in the process of setting up seven regional health improvement centres which are to be advised on the implementation of best practices culled both from domestic and foreign experience by a second central agency. Here, the idea is that the proximity of the regional centres and their independence from centralised bureaucrats will make them best placed to respond to local requirements, while the central agency can act as a nation-wide resource.

11. Such conditions are specified in the III/1993 Act on Social Provisions. 


\section{The old-age pension system}

14. The social security reform of 1997 sought to improve the long-term viability of the Hungarian public pension system by introducing a gradual increase of the statutory retirement age to 62 years, progressively replacing the PAYG system with a two-pillar scheme and moving towards a "Swiss indexing system", which adjusts benefits by an average of inflation and wage increases. The reform was initially motivated by a desire to move forward in time the payment of the unfunded liability represented by the original PAYG system (see Annex I in OECD, 1997 and Ministry of Finance, 1997) so as to limit the significant fiscal burden that an unmodified regime would have begun generating after 2030. According to projections made at that time, the inherited PAYG plus first pillar components of the reformed system would run deficits until about 2008 (which were to be covered by budgetary transfers), then enter a surplus until about 2017 before generating a deficit of about 0.5 per cent of GDP until mid-century. In order to encourage people to opt for the new system, the original reform package included an explicit promise that, in return for giving up 26 per cent of their accumulated PAYG benefits, workers who voluntarily joined the two-pillar scheme would be allowed to pay 8 per cent of gross wages into their private retirement accounts. The reform was structured to appeal to younger workers so that those older than 36-40 years of age would remain in the PAYG system. ${ }^{12}$ As it turned out many more older workers opted for the new plan than was initially anticipated (Table 2) and while they have until December 2002 to return to the original PAYG system, few are expected to do so.

15. Since its implementation in July 1998, the government has changed the parameters of the reformed pension system several times. When initially passed the reform foresaw an individual's contributions to the PAYG pension system of 1 per cent of gross wages. An additional 6 per cent, rising to 7 and 8 per cent in 1999 and 2000 was to be paid into his or her private savings account - forming the basis for their private section pension. In the event, the government doubled the personal contribution to PAYG, raising it to 2 percentage points and held the private contribution to 6 per cent - initially as a temporary two-year measure effective as of January 1999. Most recently, the government has decided to maintain these contribution rates at least until the end of 2002 while abolishing the mandatory nature of the second pillar. Implicitly recognising that these changes reduce the attractiveness of the second pillar system the government has extended to the end of 2002 the deadline after which voluntary participants (those who were employed before July 1998) will no longer be able to return to the PAYG system.

16. Part of the motivation for these changes appears to have been a 1997 binding resolution of parliament requiring that the government ensure that the private pension system contribute to the costs of invalidity and survivor pensions as well as old-age pensions. Under the original legislation the private funds were required to provide annuities, which when combined with the reduced PAYG benefit would be equal to at least 93 per cent of the PAYG old-age pension. However, no such requirement was imposed upon them for the invalidity or survivor's pensions. The authorities appear, at least in the short run, to have responded to the 1997 decree by using money originally intended for individuals' savings under the private pension system to pay for the invalidity and survivor's benefits. In so far as these are otherwise paid from general revenues, this solution minimises the government's deficit but does so at the risk of undermining the financial viability of the pension reform by substantially reducing the funds available to pay for the second-pillar portion of individual's old-age pensions. Moreover, the retroactive changing of the parameters of the regime may contribute to the perception that the new scheme is more a government tax and spending programme rather than a private pension system, with potentially important moral hazard effects on individual behaviour. Finally, the fiscal impact of changing the disability and survivor benefit procedures has not been presented in a transparent manner.

12. See Rocha and Vittas (2000). 
Table 2. Participation in mandatory private pension funds

2000

\begin{tabular}{|c|c|c|c|c|c|c|c|c|c|c|}
\hline \multirow[t]{2}{*}{ Age group } & \multicolumn{4}{|c|}{ Economically active persons, October-December } & \multicolumn{4}{|c|}{$\begin{array}{l}\text { Members of mandatory private pension funds, } \\
31 \text { December }\end{array}$} & \multicolumn{2}{|c|}{$\begin{array}{l}\text { Per cent of economically } \\
\text { active persons who are: }\end{array}$} \\
\hline & Male & Female & Total & $\begin{array}{c}\text { Per cent } \\
\text { of total }\end{array}$ & Male & Female & Total & $\begin{array}{l}\text { Per cent of } \\
\text { total }\end{array}$ & Members & $\begin{array}{c}\text { Non- } \\
\text { members }\end{array}$ \\
\hline $15-19$ & 40200 & 31200 & 71400 & 1.7 & 37428 & 43863 & 71291 & 3.6 & 99.8 & 0.2 \\
\hline $20-24$ & 289700 & 206500 & 496200 & 12.0 & 200546 & 212350 & 412896 & 20.9 & 83.2 & 16.8 \\
\hline $25-29$ & 356300 & 235200 & 591500 & 14.3 & 228942 & 237977 & 466919 & 23.6 & 78.9 & 21.1 \\
\hline $30-34$ & 318200 & 212500 & 530700 & 12.8 & 190286 & 184886 & 375172 & 19.0 & 70.7 & 293 \\
\hline $35-39$ & 267000 & 232800 & 499800 & 12.1 & 139918 & 153508 & 293426 & 14.8 & 58.7 & 41.3 \\
\hline $40-44$ & 294200 & 284400 & 578600 & 14.0 & 105738 & 124038 & 229776 & 11.6 & 39.7 & 60.3 \\
\hline $45-49$ & 307200 & 314200 & 621400 & 15.0 & 51503 & 60981 & 112484 & 5.7 & 18.1 & 81.9 \\
\hline $50-54$ & 239500 & 230000 & 469500 & 11.3 & 6907 & 6898 & 13805 & 0.7 & 2.9 & 97.1 \\
\hline $55-59$ & 147800 & 75200 & 223000 & 5.4 & 1108 & 395 & 1575 & 0.1 & 0.7 & 99.3 \\
\hline $60-64$ & 26100 & 14700 & 40800 & 1.0 & $98^{1}$ & $20^{1}$ & $118^{1}$ & $0.0^{1}$ & $0.3^{1}$ & $99.7^{1}$ \\
\hline $65-69$ & 9800 & 6600 & 16400 & 0.4 & & & & & & \\
\hline $70-74$ & 3800 & 2400 & 6200 & 0.1 & & & & & & \\
\hline Total & 2299800 & 1845700 & 4140500 & 100.0 & 962546 & 1014916 & 1977462 & 100.0 & 49.0 & 51.0 \\
\hline $\begin{array}{l}\text { Gender group } \\
\text { as per cent of total }\end{array}$ & 55.5 & 44.5 & 100.0 & & 48.7 & 51.3 & 100.0 & & & \\
\hline
\end{tabular}

1. 60 and above.

Source: Financial Markets Supervision. 
17. Participants in the PAYG scheme are predominantly older workers who chose not to join the new two-pillar scheme. Benefits are calculated as a percentage of the average of the contributors' wages since 1988 with wages (except in the last three years before retirement) indexed for inflation. Replacement rates start at 43 per cent of average net earnings (calculated in this way) after 15 years of service (for details, see Box 12). Once an initial pension benefit is determined, subsequent years' benefits are indexed according to a weighted average of anticipated net-wage growth and inflation (the weights of 70 and 30 per cent respectively in 2000 have been equalised at 50 per cent in 2001). If actual wage growth or inflation turn out higher than expected, benefits are to be increased accordingly in the second half of the year.

\section{Box 2. The social-security pension system}

\section{Old-age pensions}

The Hungarian social-security pension system consists of a classic pay-as-you-go scheme (PAYG) and a two-pillar system composed of a modified version of the PAYG system plus a compulsory fully-funded scheme. In addition, since 1993 individuals can supplement their savings through participation in a privately owned voluntary pension fund (see Box 3). Participation in the two-pillar system was mandatory for all new entrants to the labour force since July 1998 until December 2001. Those already employed prior to that date were allowed to join the new scheme up to September 1999. Initially, they were allowed to reverse this decision until the end of 2000 after which they would have been obliged to remain in the new system. Following changes to the conditions of the system this deadline has been extended to the end of 2002. Persons covered by the two-pillar system are entitled, under the first pillar, to 74 per cent of the benefits provided by the old PAYG scheme, plus an annuity based on accumulated assets in their individual retirement accounts. Until the mid-2010s, the bulk of public pension benefits will be paid by the old PAYG.

\section{Financing and administration}

Since 2002, the contribution of employers to cover both PAYG and first pillar benefits is 18 per cent of gross wages. Revenues and expenditures of the PAYG system are integrated into the general revenues and the government is responsible for covering its deficits, if they arise. The administration of this statutory pension scheme is performed by the Central Administration of Pension Insurance, a public agency supervised by the Ministry of Finance. Thus, its deficits form a part of the general government balance. Employees participating exclusively in the PAYG system contribute 8 per cent of their gross wages to it, while those participating in the two-pillar scheme pay 2 per cent to the first pillar and 6 per cent to their individual pension accounts, which are administered by private pension funds they have chosen. Individual contributions are subject to a ceiling equal to the contribution of someone earning twice the average wage. The 2 per cent of gross wages currently transferred to the PAYG system by individuals participating in the two-pillar scheme were supposed to be completely allocated to their individual pension accounts by 2000 , bringing their contribution to the fully-funded scheme to 8 per cent. An additional 1 per cent contribution was to be introduced and paid to the PAYG system. In the event, the government has decided to maintain the 2 per cent contribution to the PAYG system until the end of 2002, if not longer.

\section{Benefits}

The old-age pension is the principal component of the Hungarian social security system for older citizens. The relatively low statutory retirement age ( 60 years for men, 55 years for women) has been gradually increasing since 1996 and is scheduled to reach 62 years for both genders by 2009 . Old-age pensions are not currently taxable although they form part of the tax base when defining marginal rates. As of 2013, when the second pillar pension funds are scheduled to start paying annuities, all pension income from the new scheme will become taxable. 
To establish entitlement to a full pension, 20 years of participation in the PAYG scheme are required (15 years for a partial one). ${ }^{1}$ Exceptions are allowed for workers in a few hazardous occupations as well as those unemployed persons entitled to various early retirement schemes. The PAYG old-age pensions are calculated on the basis of the contributions paid and the length of service but are adjusted so as to raise those of lower income workers and reduce those of better paid ones. The base for calculating the pension benefit is average net earnings adjusted for inflation for the period from 1 January 1988 to three years before retirement, while the wages in the last three years are not indexed. ${ }^{2}$ A contribution period of 15 years establishes the right to a pension amounting to 43 per cent of average net earnings (calculated as above). The next 10 qualifying years increase the replacement rate by 2 percentage points per annum to 63 per cent. Each additional year of service between 25 and 36 years earns an additional percentage point, increasing the replacement rate up to 74 per cent. After the $36^{\text {th }}$ year, the accrual factor is 1.5 percentage points per annum. After 38 years, and provided that the statutory retirement age has been reached, the calculated retirement benefit increases by 0.3 per cent for each additional month of service. In 2000, those whose pensionable earnings exceed 55000 forints (approximately the average net wage) have their pensions clawed back at an increasing marginal rate that tops out at 90 per cent for pensionable earnings in excess of 141000 forints per month (the so-called degression factor). The bulk of PAYG pensions is spread in the interval between one-half and two average wages.

As of 2013, the PAYG pension will be defined as a proportion of average gross earnings calculated in the same way as above with the benefit level increasing by 1.65 percentage points for each qualifying year in excess of the minimum of 20 years. The first-pillar pension for retirees with individual pension accounts in the fully-funded scheme will increase by 1.22 per cent of average gross income for each year of service. ${ }^{3}$ After 2013, "excess" pensions will no longer be subjected to claw back.

Pensions were indexed to wages from 1992 to 1999 when the government imposed an average increase of 14 per cent rather than 18 per cent implied by the formula, while limiting individual increments to a maximum of 11 per cent or 3500 forints, thereby increasing significantly the lowest pensions. Pensions in following years were to be indexed according to a "Swiss formula" equal to a weighted average of the increase in wages and prices, with the weights being 70 and 30 per cent in 2000 and 50-50 afterwards. Actual increases exceeded the amounts implied by the formula by a few percentage points up to and including 2002.

\section{Disability pensions}

The minimum service period necessary to qualify for a full disability pension is age-dependent, rising from 2 years for persons 22 years old or younger to 20 years for members of the 55+ age group. The qualifying periods for a partial disability pension are 25 per cent shorter. If disability results from a work-related accident or occupational disease, the minimum service requirement is waived. The calculation of disability pensions is similar to that of the retirement pension except that the expected number of years of service is substituted for the actual number and the size of the pension adjusted according to three levels of disability. The first two categories include invalids who are unable to work or unable to live without care provided by others. The third category consists of persons with light disability who are unable to obtain regular employment; recipients of light-disability benefits are to be reviewed regularly (every 2-3 years). In the case of invalidity or work-related disability, a participant in the reformed scheme of pension insurance either transfers fully to the PAYG system, losing the contributions to the individual account which accrue to the government but gaining the right to the maximum amount of the applicable invalidity pension, or is allowed to keep the sum accumulated in the private retirement account and receives the reduced amount of the applicable pension. 


\section{Survivor pensions}

A surviving spouse of an old age or invalidity pensioner is entitled to a temporary pension for one year, amounting to 50 per cent of the deceased's pension. If the surviving spouse satisfies one or more relevant criteria (statutory retirement age, disability, two or more orphaned children) within ten years, then she (or he) is entitled to a permanent widow's (or widower's) pension amounting to one-half of the deceased spouse's actual or projected pension. If the surviving spouse receives his or her own pension already, the permanent pension is reduced to one-fifth of the deceased spouse's pension. Children are entitled to receive 30 per cent of their dead parent's pension up to the age of 16 or up to a maximum of 25 years of age as long as they are studying. If both parents die, the allowance rises to 60 per cent of the higher of the deceased parents' pensions. The PAYG system also provides similarly defined survivor benefits for parents or grandparents, provided that the contributor's death was related to a workplace accident or occupational disease. To assure the payment of a full amount of survivor pensions, the deceased contributor participating in the reformed pension scheme is deemed to have switched fully to the PAYG system. This is a temporary solution to a problem resulting from time lags in the implementation of the pension reform that included provisions for disability and life insurance within the second pillar.

\section{Unresolved transitional issues}

The move to the new pension scheme has been gradual. While many of the problems that this process will entail have been addressed by law, there are some issues that have yet to be resolved. Thus, while the government currently establishes each year the level of minimum old-age pension, according to legislation, this benefit is to be phased out in 2009. This means that eligibility for the old-age welfare benefit, which is defined in terms of this benefit, will have to be modified in a way not yet determined. It is also unclear whether (or how) the disability and life insurance provisions (see above) will be integrated into the reformed system in the foreseeable future. Finally, the current legislation does not clarify tax treatment of the PAYG pensions after 2013 (benefits from the new two-pillar scheme will be subjected to income tax after this date). Either PAYG benefits approved before 2013 will continue to be paid on a non-taxable basis, which would create two types of tax regimes for working retirees, or these benefits will be adjusted in a manner that would make a uniform tax treatment possible.

1. Partial pension benefit will be phased out in 2009 .

2. The multipliers used to adjust nominal earnings at time $t$ are based on the net wage index at time $t+2$. For instance, a worker retiring in year 2000 has his net earnings adjusted for inflation from 1988 to 1996, the multiplier for the last year being 1.469 .

3. The coefficient of 1.22 per cent reflects the relationship between the first pillar pension and PAYG benefit.

18. Workers covered by the new two-tier system included until 2002 all new entrants to the labour market as well as those, generally younger workers, who chose to opt for it when it was introduced during 1998. From January 2002 participation is optional for all workers. Participants in the reformed system who retire before 2013 earn a first pillar pension equal to 75 per cent of that calculated from the same formula as above plus the largest annuity that their contributions to the pre-funded scheme are able to support. However, if the resulting annuity exceeds 50 per cent of the first pillar portion of their benefit, they may opt to receive the capital component of their surplus as a lump sum. Moreover, the government guaranteed that the annuity would be at least large enough to yield total pension equal to 93 per cent of the PAYG benefit, providing that the recipient will have participated in the reformed system for at least 15 years (see Box 3). However, the authorities decided to abolish this statutory guarantee in 2001. After 2013, a new formula applies to the calculation of pensions (see Box 2) resulting in a first pillar pension amounting to 74 per cent of the PAYG benefit. 


\section{Box 3 . The privately managed pension funds}

The second pillar of the reformed pension system consists of defined-contribution funds, into which a portion of individuals' mandatory social-security contributions are transferred. The third and voluntary component of the Hungarian social-security system is also provided by defined-contribution pension funds. These ones have been operating since 1993. Some 1.3 million citizens (one-quarter of the employed) participate in the voluntary scheme, whereas the compulsory funds have approximately 2.1 million members. The funds accumulated over six years in the private retirement saving plans of the third pillar are equivalent to some 1.3 per cent of GDP which is slightly more than the amount accumulated over 2 years in the second pillar ( 0.8 per cent of GDP). The authorities expect that the volume of funds in all private retirement accounts would increase to 10 per cent of GDP by 2010 and keep growing to reach 50 per cent of GDP by 2050 .

\section{Financing and administration}

The compulsory pension funds are non-profit institutions that invest money deposited in their members' private retirement accounts. Currently, the standard rate of deposit amounts to three-quarters of the employees' pension contributions deducted from the gross wages subject to an upper limit (see Box 2) with the other 25 per cent being used to offset the PAYG deficit. There are 31 funds in operation, the largest ones having been established by banks, insurance companies and large corporations. After 15 years, contributions are vested but prior to then an individual or his beneficiaries can withdraw them as a lump sum or an annuity. There are four types of life and term annuities which are based on actuarial principles except for the requirement that identical life tables must be used for both men and women. Annuities under the compulsory system are to be indexed in the same or more generous (at the discretion of the pension funds) manner as PAYG pensions. Fixed-term and last survivor annuities can be inherited by designated beneficiaries. If an individual's annuity exceeds 50 per cent of his first pillar pension, he may elect to receive a lump sum payment and a reduced annuity equal to not less than one-half the income stream from the first pillar.

The voluntary retirement savings plans are administered by 238 funds. Since 1993 some 30 of them have ceased to operate due to mergers or liquidation. The industry is dominated by a small number of large funds that were set up by large financial groups and corporations. Contributions in the individual retirement savings plans are to be converted into annuities based on actuarial principles. Tax incentives reward voluntary contributions by deferring the income tax payable on the employees' contribution until the annuity is paid and by providing tax relief to employers who contribute to employees' voluntary schemes.

\section{Supervision}

The Finance Ministry regulates the activities of all private pension funds which are supervised by a specialised agency responsible for licensing, monitoring and corrective activities (the state financial markets supervision PSzÁF). The 31 pension funds active in the compulsory scheme have to meet the same administrative, accounting, valuation and actuarial reporting requirements as the 238 funds in the voluntary scheme. The form of these reports as well as investment standards governing the operation of pension industry are established by PSzÁF but must be issued by the government. Legislation obliges the funds to report their rate of return calculations using two methods, one including and the other net of operating costs.

In order to protect against the failure of a particular fund, contributions to the individual retirement accounts in the second-pillar funds are subjected to a 0.4 per cent surcharge that is used to finance a Guarantee Fund. The minimum second-pillar annuity is defined as one-quarter of the first-pillar 
benefit and is to be paid by the Guarantee Fund if an individual's own accumulated assets prove inadequate. If the Fund is unable to pay, the central government is legally obliged to provide it with a loan to make up the difference. Further, the government will supplement individual pensions if the combined retirement benefit (first pillar + annuity) is less than one-half of the average pension, providing that the recipient lives in a household with an income below the poverty level.

\section{Investment and minimum return rules}

Pension funds can invest on regulated markets in a wide range of securities that are classified into three portfolio categories, reflecting different risk and liquidity levels. The compulsory pension funds must keep at least 10 per cent of assets in the lowest-risk category, up to 60 per cent in the intermediate-risk category and not more than 30 per cent in the riskiest one. The corresponding percentages for the voluntary funds are 0,70 and 30 . The proportion of foreign investments in the overall portfolio of a second-pillar fund had been restricted to nil in 1999 and 10 per cent in 2000. Beginning in 2002, the maximum foreign content is 30 per cent of the investment portfolio while at most 10 per cent may consist of investments in non-OECD countries. A 20 per cent maximum on foreign securities already applies to voluntary funds.

In addition, compulsory pension funds are subjected to quantitative return rules. Fund performance is categorised as low, average or high depending whether the reported rate of return (see above) is currently less than 85 per cent of the long-term government bond index, between 85 and 140 per cent of the index or more than 140 per cent. ${ }^{1}$ A failure of a fund to exceed the lower limit ( 85 per cent) for three consecutive years triggers an investigation by the supervising authority. Funds must build reserves against performance fluctuations relative to this band. The value of reserves should be equal to between 0.5 and 4 per cent of assets. These reserves are to be used to top up individual retirement accounts in the periods of low-investment returns. The actual investment behaviour of the pension funds has been very cautious to date with some four-fifths of assets invested in Hungarian government securities.

1. The limits can be set annually by PSzÁF without requiring government approval.

19. Workers in both systems pay a compulsory contribution of 8 per cent of their wages, while employers make a contribution of 18 per cent. For those covered by the PAYG system only, the entire 8 per cent employee contribution is paid to general revenues, while for those in the two-pillar system the contribution is split between their fully-funded account and general revenues, with 6 percentage points currently going to the former. Both employers' and employees' contributions are deductible from corporate and personal income tax respectively. Employees can "top up" their contribution to their compulsory pension fund up to a maximum of 10 per cent of their gross wages. Furthermore, additional contributions may be also made into voluntary pension funds operating in Hungary since 1993.

\section{The economic implications of ageing under existing institutional arrangements}

20. The ageing of Hungary's population will have important economic ramifications. The shrinking of the population and the even more rapid decline in the labour force will mean that at any level of productivity or taxation less output and revenues will be available. Meanwhile, rising dependency rates suggest that demands on the support system will be higher than currently. The following paragraphs seek to quantify the implications of these demographic developments and expected technological progress on output, savings behaviour and on the balance between the revenues available to finance elderly support programmes and the expenditures that are likely to be generated. While necessarily speculative, by quantifying the range of potential outcomes (given reasonable assumptions), such simulations should help 
to provide a coherent framework in which to identify and analyse some of the most serious challenges that will arise as Hungarians grow old. Policies to address these problems are discussed in the next section.

\section{Macroeconomic implications}

21. From a macroeconomic perspective, the ageing and decline of Hungary's population will mean that as the labour force shrinks there will be fewer workers to produce the goods and services needed to supply a growing dependent population. Assuming that progress in the structural reform continues, technological advances, investment and the catch-up process should help ensure that improvements in productivity more than keep pace with developments elsewhere in the world. Over a period of 50 years, economic performance depends on employment, investment and productivity trends. The employment projections presented earlier indicate that employment levels will begin falling by about 2010 and that by mid century they could be falling by 0.7 to 1 per cent per year, implying lower output growth. Fortunately for Hungary, there is every reason to believe that it will continue to enjoy relatively strong productivity growth. While demographic developments can have an impact on productivity, ${ }^{13}$ for a country like Hungary the potential productivity gains to be garnered by maintaining an open stance towards trade, foreign investment and technology are likely to dominate productivity growth for the next several decades. Indeed, economic theory and empirical results (including the recent experience of Hungary) show that by welcoming foreign capital and benefiting from technological transfer, Hungarians can enjoy substantially higher productivity growth than more developed countries. However, over time, as the gap between the output per Hungarian worker and that of other OECD workers narrows, Hungarian productivity growth will slowly converge towards international rates of technological improvement. Working within this framework and, assuming that, over and above trend technological progress, the gap between Hungarian productivity levels and those in the United States narrows by 2 per cent each year, Hungarian productivity can be expected to reach about 80 per cent of American levels by 2050 (Table 3). However, as catch-up progresses Hungary's productivity growth rates will slow to below 2.5 per cent in the $2040 \mathrm{~s}$. As a result, GDP growth can be expected to decline sharply from its current high levels of some 5 per cent a year to between 1.4 and 1.7 per cent per annum by mid-century. ${ }^{14}$

22. This long-term growth process presumes the accumulation of stocks of physical capital that embody state-of-the-art-technology. Notwithstanding strong foreign capital inflows, the financing of the associated investment flows will need to be provided mainly by domestic savings, which may well be influenced by the ageing of the population. The life-cycle model of savings makes clear predictions about the savings behaviour of individuals during their lifetimes that are, however, supported only weakly by empirical evidence. ${ }^{15}$ As the population ages, ceteris paribus, savings should first rise, as the bulk of individuals reach their primary earning years, and then decline as they stop working and begin dissaving. A

13. For instance, the higher productivity growth rates of youths means that ceteris paribus a young population can be expected to have a higher aggregate productivity growth rate. However, because older workers have higher productivity levels, an ageing society as compared to a stable population would be expected to see better aggregate results as the share of high productivity workers rises, even if their individual growth rates were lower.

14. The extent of catch up and the speed of productivity growth depend on both the long-term trend for technological progress (TP) and the additional catch-up parameter employed (KUP). In the simulations, an optimistic value for TP of 1.75 per cent was used and an empirically observed catch-up factor of 2 per cent of the existing productivity gap. Alternative scenarios assuming TP $=1.5$ and KUP of 1, 1.5, 2.5 and 3 per cent were also simulated.

15. Predictions generated by life-cycle models of savings have not always been consistent with observed data; this may be due to the uncertainty as to date of death and bequests. See Kohl and O'Brien (1998), and Pecchenino and Utendorf(1999). However, the life-cycle hypothesis performed rather well in crosscountry studies. See Hviding and Merette (1998). 
social security scheme can, by forcing some individuals to save more than they would otherwise, increase the national savings rate. Indeed, empirical and theoretical evidence suggests that schemes such as Hungary's, which are mandatory, tax benefits and discourage borrowing against accumulated pension assets can have a positive impact on household savings (Bailliu and Reisen, 1997).

Table 3. Growth rates of employment, productivity and GDP

\begin{tabular}{|c|c|c|c|c|c|c|c|}
\hline & & 2000 & 2010 & 2020 & 2030 & 2040 & 2050 \\
\hline \multicolumn{8}{|l|}{ Employment $^{1}$} \\
\hline \multirow[t]{2}{*}{ All scenarios } & Index $2000=100$ & 100.0 & 108.0 & 102.9 & 97.5 & 88.4 & 82.5 \\
\hline \multirow{2}{*}{\multicolumn{8}{|c|}{ Labour productivity ${ }^{2}$}} \\
\hline & & & & & & & \\
\hline \multirow[t]{2}{*}{ Slower growth } & Index $2000=100$ & 100.0 & 143.9 & 193.5 & 249.8 & 313.8 & 387.0 \\
\hline & Average growth rate ${ }^{3}$ & & 3.7 & 3.0 & 2.6 & 2.3 & 2.1 \\
\hline \multirow[t]{2}{*}{ Faster growth } & Index $2000=100$ & 100.0 & 147.4 & 203.1 & 268.7 & 346.1 & 437.4 \\
\hline & Average growth rate ${ }^{3}$ & & 4.0 & 3.3 & 2.8 & 2.6 & 2.4 \\
\hline \multirow{2}{*}{ Faster growth, slower catch-up } & Index $2000=100$ & 100.0 & 140.8 & 189.8 & 248.8 & 319.4 & 404.0 \\
\hline & Average growth rate ${ }^{3}$ & & 3.5 & 3.0 & 2.7 & 2.5 & 2.4 \\
\hline \multicolumn{8}{|l|}{ Real GDP } \\
\hline \multirow[t]{2}{*}{ Slower growth } & Index $2000=100$ & 100.0 & 155.4 & 199.0 & 243.3 & 277.2 & 318.8 \\
\hline & Average growth rate ${ }^{3}$ & & 4.5 & 2.5 & 2.0 & 1.3 & 1.4 \\
\hline \multirow[t]{2}{*}{ Faster growth } & Index $2000=100$ & 100.0 & 159.2 & 208.9 & 261.7 & 305.7 & 360.3 \\
\hline & Average growth rate ${ }^{3}$ & & 4.8 & 2.8 & 2.3 & 1.6 & 1.7 \\
\hline \multirow[t]{2}{*}{ Faster growth, slower catch-up } & Index $2000=100$ & 100.0 & 152.0 & 195.3 & 242.3 & 282.2 & 332.8 \\
\hline & Average growth rate ${ }^{3}$ & & 4.3 & 2.5 & 2.2 & 1.5 & 1.7 \\
\hline
\end{tabular}

1. Employment is measured in person-years and corresponds to Scenario I (improved employment rates) of Figure 2.

2. Labour productivity is measured by real GDP per worker and is estimated as follows: $\mathrm{Ht}=(1+[\mathrm{TP}] / 100)[\mathrm{Ht}-1]+$ $c[U t-1-H t-1]$ and $U t=(1+[T P] / 100)[U t-1]$ where $\mathrm{Ht}$ and $\mathrm{Ut}$ are respectively Hungarian and American labour productivity in year t, TP is the long-term average rate of technological progress in per cent and $c$ is the catch-up factor.TP is assumed to be 1.75 per cent in the faster growth scenarios and 1.5 per cent in the slower growth scenario.c is the fraction of the productivity gap that is gained each year over and above the trend rate of growth and is 1.5 per cent in the faster growth, slower catch-up scenario and 2 per cent in the others.

3. Per cent, average annual growth rate over the preceding 10 years.

Source: OECD.

23. The authorities expect that the value of assets accumulated by Hungarian pension funds will grow from 0.8 per cent of GDP in 1999 to about 50 per cent by 2050, resulting in a rapidly growing pool of domestic capital that ought to be available for financing investment of domestic firms. However, it would be mistaken to assume that all of the savings to be generated by the fully-funded scheme will represent a net addition to savings as, for many individuals, the system's forced savings will just displace voluntary savings that would have taken place anyway. Indeed, although Hungarians have responded enthusiastically to the introduction of the new pension scheme, neither the stock of savings it represents, nor its rate of accumulation are overwhelming (Table 4). Furthermore, these forced savings are being offset, to some extent, by government dissaving as it is obliged to finance the deficit of the PAYG system. Even optimistic assumptions imply that the growing weight of pre-funded pensions will have, at most, a moderate positive effect on the national saving rate. As a result, Hungary is likely to continue relying on, and benefiting from, foreign savings to finance the investments that will enable it to grow and converge to OECD income levels as rapidly as outlined above. 
$\mathrm{ECO} / \mathrm{WKP}(2002) 24$

Table 4. Membership and assets of Hungarian pension funds ${ }^{1}$

\begin{tabular}{lrrrrrr}
\hline & 1995 & 1996 & 1997 & 1998 & 1999 & 2000 \\
\hline Voluntary private funds & & & & & & \\
Members (thousands) & 194.40 & 464.30 & 675.00 & 939.29 & 1007.36 & 1082.19 \\
Assets (per cent of GDP) & 0.12 & 0.34 & 0.65 & 1.00 & 1.34 & 1.72 \\
Mandatory private funds & & & & & \\
Members (thousands) &.. &.. &.. & 1346.70 & 2064.14 & 2175.49 \\
Assets (per cent of GDP) &.. &.. &.. & 0.29 & 0.77 & 1.34 \\
\hline
\end{tabular}

1. End of year.

Source: Financial Markets Supervision.

\section{Fiscal impacts}

24. The combination of slowing GDP growth and rising dependency ratios has the potential to create serious fiscal difficulties by simultaneously slowing revenue growth and increasing spending burdens. Evaluating the long-term fiscal sustainability of a country's old-age support system is fraught with uncertainty, although the exercise is essential in order to provide a basis for informed policy discussions. This is all the more relevant when decisions made in response to short-term or temporary problems can have long-run consequences. Indeed, the demise of the existing PAYG pension system was contributed to by the decision to respond to the rapid rise in unemployment in the early 1990s with extensive early retirement schemes. A policy, which increased the system's financial burdens (see Figure 4) at a time when the number of contributors (and hence its ability to pay) was declining. ${ }^{16}$

25. Currently, the Hungarian economy is in a much better position than at the beginning of the transition. Moreover, the demographic crunch will not hit for another twenty years and, as a result, there is time to put in place forward-looking reforms to limit the fiscal strain in the future. As the overall dependency ratio rises after 2015 (Figure 5), the fiscal burden from increased health, social insurance and pension costs is expected to increase unless action is taken to forestall these developments. ${ }^{17}$ The

16. Indeed, between 1990 and 1999, public pension spending surged by more than 10 per cent of GDP while the ratio of pensioners to contributors jumped from 46.1 to 71.8 per cent (Csaba and Semjen, 1999). Short-run fiscal stability was only restored following the implementation of a necessary, albeit unpopular, package of spending cuts.

17. According to UN estimates, the old-age dependency ratio in Hungary will rise continuously over the period 1995-2050 (Figure 5, Panel A) but a relatively rapid fall in the size of the 0-19 cohort means that the total dependency ratio will actually decline until about 2015, after which it begins to rise. Throughout the next fifty years, Hungary's old-age dependency ratio is expected to differ little from the OECD average, while low birth rates (and hence a relatively small youth population) mean that the overall dependency ratio reaches the OECD average at the end of the projection period. In Panel $\mathrm{B}$, the dependent population is compared with the employed working-age population assuming no change in the 1999 aggregate employment rate. Hungary's relatively low utilisation as compared with other OECD countries means that its old-age dependency ratio exceeds the OECD average during the entire period projected while the overall dependency ratio falls below the OECD average over the period 2012-35 but increases sharply in following years. 


\section{ECO/WKP(2002)24}

Figure 5. Dependency ratios

Per cent
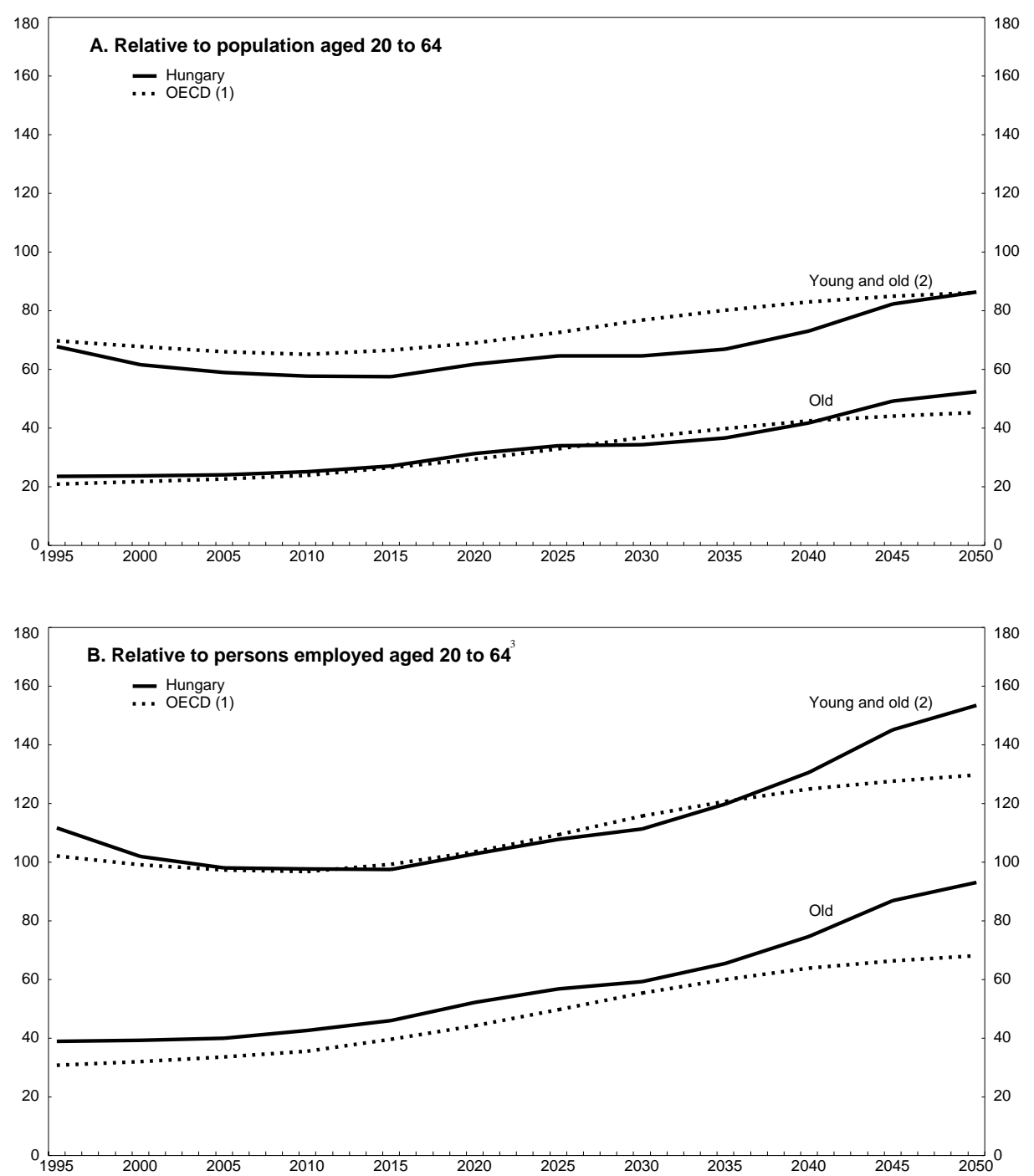

1. Excluding Switzerland

Young are defined as aged 0 to 19 and old as 65 and over.

. For all years, employment of persons aged 20-64 is estimated by sum of the product of the cohort-specific employment-population ratio

Source: United Nations Population Division, World Population Prospects: The 1998 Revision; OECD. 
simulations described in the paragraphs that follow attempt to illustrate the pressures that the ageing of the Hungarian population would exert upon the social security system in the unlikely event that it were not modified. Their purpose is not to judge the system per se but to highlight tensions in an effort to identify areas where policy reform is most likely to be successful. They measure this fiscal pressure via the "social security deficit", which is defined as the difference between the revenues tied to the healthcare and pension systems and associated expenditures, plus the net increase in expenditures associated with ageing but financed from general revenues (such as the old-age benefit, transfers in kind, etc.). ${ }^{18}$ The simulations, which, unless explicitly indicated otherwise, assume that the parameters of the system including tax rates remain unchanged.

\section{Healthcare expenditure}

26. The impact of ageing on healthcare expenditure is not straightforward. It is generally true that older individuals have more health problems and higher associated expenditures than younger ones. However, it is also true that most of these expenditures are generated in the last few years of life -- independent of how old the person might be when they die. Therefore, a population that lives longer need not cost significantly more to care for, although for a given life expectancy the older the population, the more expensive it will be. While there may be room for meeting some of the increased social security and health costs associated with ageing with savings from reduced youth-related social and educational spending, the fact that spending on old-age related social security is approximately three times as high as that on education and childcare benefits suggests that the potential for substitution is limited. More important in predicting healthcare expenditures in Hungary is the influence of demand-side pressures. Experience within the OECD indicates quite clearly that as incomes rise, demand for healthcare increases more rapidly. ${ }^{19}$ OECD estimates suggest that the healthcare demand of the population less than 60 years old will remain a relatively stable proportion of GDP over the next 50 years. However, because of ageing and higher demand per capita, the demands of the population over 60 years of age would rise from some 2.5 per cent of GDP now to almost 6 per cent (Figure 6). Thus, unless mechanisms are put in place to improve the efficiency of the healthcare delivery system, raise revenues or allow for more private provision of services, its deficit (currently 0.8 per cent of GDP) could be expected to reach some 5.7 per cent of GDP by $2050 .^{20}$

18. The "deficit" in this sense is notional and could be closed by higher social security contribution rates, although the feedback on employment and growth from higher taxes would reduce the contribution base.

19. Murillo (1993) provides estimates of demand and price elasticities for healthcare, which suggest that the lower the level of development of a country the more rapidly healthcare demand rises. However, as Mahieu (2000) indicates, these elasticities fall below unity when additional factors are taken into account. Nevertheless, because these factors tend to be correlated with income, the gross demand elasticities are generally acknowledged as reasonable proxies for long-term developments.

20. These simulations assume that productivity and employment grow as described in the preceding section and that health care has an income elasticity of demand of 1.25 , which is substantially less than the 1.4-2.0 elasticities suggested by the literature (see Mahieu, 2000 and Murillo, 1993). 
Figure 6. Demand for health services

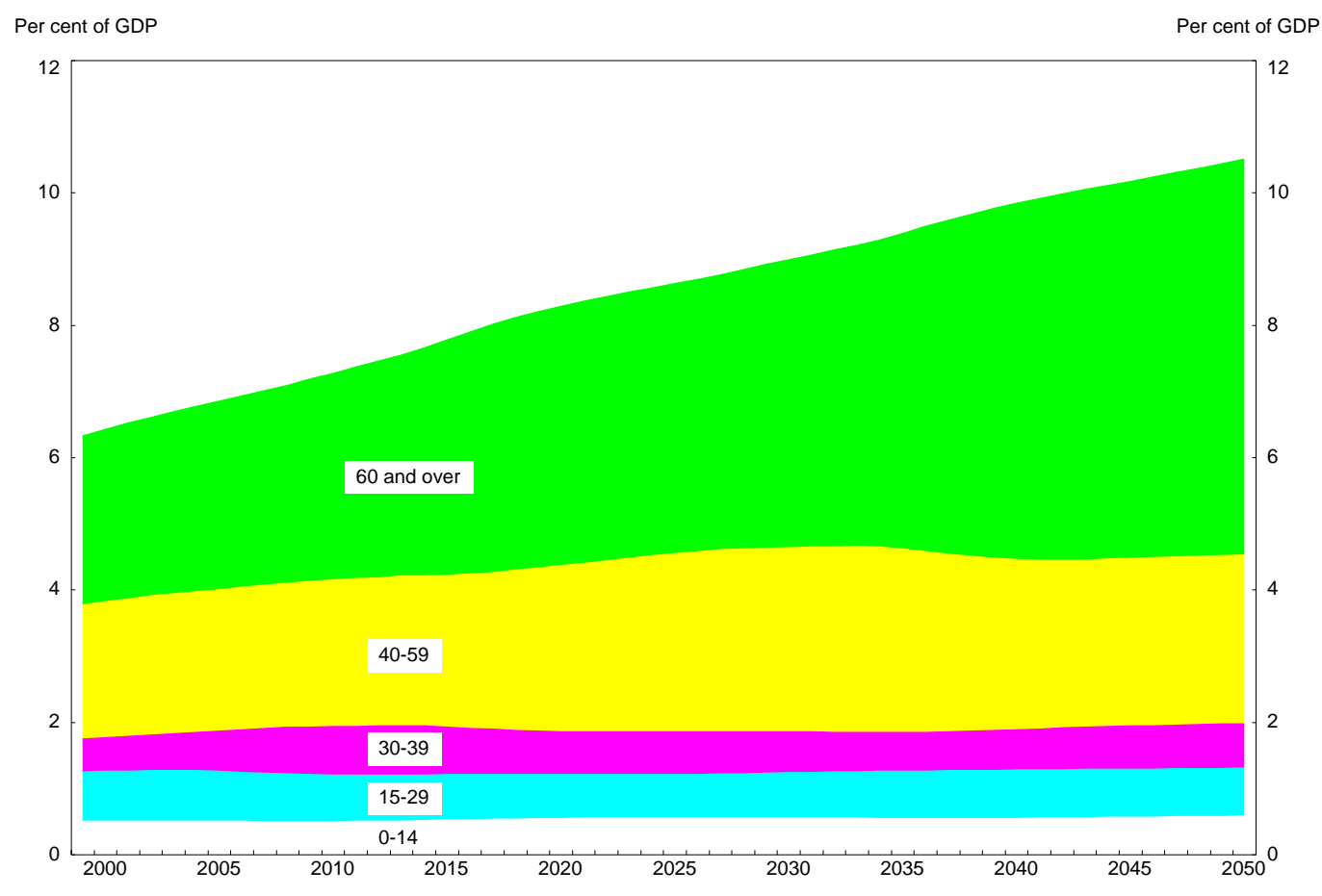

Source: OECD projections using data from the Demographic Institute of the Central Statistical Office.

\section{Social assistance spending}

27. Another component of the old-age social-security deficit consists of welfare benefits for the elderly. Although only 10000 individuals are currently receiving them (see above), their importance is likely to grow because overall employment rates are much lower now than they were under communism and both long-term unemployment and self-employment are more prevalent. As a result, an increasing share of each retiring cohort is likely not to have worked long enough to qualify for a pension. OECD estimates suggest that, even with substantial improvements in the overall employment rate and assuming normal turnover of the non-employed population, the number of welfare-dependent seniors will gradually increase from the current level to some 150000 persons over the next 50 years. This would imply that by 2050 approximately 6 per cent of people in retirement age would depend on these benefits. ${ }^{21}$ If the value of in kind welfare benefits were to rise in line with the cash benefits, their combined budget burden would increase from the currently negligible level to 0.4 per cent of GDP by 2050 .

21. OECD long-term projections for Hungary imply an aggregate non-employment rate of about 37 per cent on average between 2000 and 2050 (changes in the demographic composition of the working age population mean the rate is not constant). If each year 9 per cent of the non-employed find work, then 6 per cent of each retiring cohort will not have the required service years. Assuming that their life expectancy is no different from the average of people at retirement age, the stock of old age benefit recipients will be about 150000 by 2050 . 


\section{Public pensions}

28. In principle, forecasting the long-term financial viability of the pension system is subject to less error than similar exercises applied to healthcare or welfare payments because its parameters, both as concerns expenditures and revenues, are well known. Nevertheless, these projections depend importantly upon the assumptions concerning future demographic, employment and productivity developments. In its official projections, the government forecasts that the PAYG portions of the pension system (comprised of both those who remained in the old system and the first-pillar payments of those having opted for the new scheme) will run a deficit until about 2008. It is then projected to generate a surplus that grows slowly to almost 1 per cent of GDP by 2030 before falling to a 0.3 per cent of GDP surplus in 2050 (see the thick solid line in Panel B, Figure 7). Adding to this the corresponding projections for the healthcare sector and the welfare benefits for the elderly yields a consolidated social security deficit by 2050 of 7 per cent of GDP that is shown in Panel A of the same figure.

29. However, the government's baseline scenario assumes that the ratio of employed to the population (15-74) will gradually rise to 60 per cent. ${ }^{22}$ While apparently reasonable, it fails to take into consideration the impact of ageing within the 15-74 years old population and the much lower employment rates of older workers. The impact of using the employment projections presented in Figure 2 (in the previous section) is represented by the dotted lines in Figure 7. Under this scenario, which sees the Hungarian employment rate for the 15-64 cohort rise from 56 per cent to 66 per cent in 2050, well above the current OECD Europe average of 60 per cent, total employment falls more quickly than in the government scenario. ${ }^{23}$ With fewer contributors, the projected surplus of the PAYG system is substantially reduced and actually turns into a deficit by 2037 . Lower income growth in this scenario, implies that healthcare spending will be more restrained so that the projected total social security deficit could be smaller by $1 / 4$ percentage point of GDP by 2050 , as compared with the government's reference scenario.

30. Another important influence on the overall pension system deficit will be productivity growth. The government scenario assumes that GDP will grow on average by about 4.6 per cent per annum in the first decade of the new millennium, before slowing until 2031 after which it will continue growing at a more modest 2.5 per cent per annum. Given current demographic projections and the employment scenarios outlined above, this would require accelerating productivity growth over the next 50 years which contrasts with both theoretical reasoning and empirical evidence. ${ }^{24}$ Substituting the OECD projections for employment and productivity yields much lower GDP growth (see Table 3 ) and, as a result, the PAYG balance remains in deficit until 2008 and returns to a negative balance from 2015 to 2022, and from 2030 until the end of the projection period (thin line, Figure 7). Indeed, by the end of the period the PAYG deficit is about 1.2 per cent of GDP, while the consolidated social security deficit reaches $8 \frac{1}{2}$ per cent of GDP. It is this scenario that is used as the baseline in the remainder of this chapter.

22. This employment rate follows Hungarian statistical traditions by defining the working-age population as 15-74 years of age. It differs from the one used by the OECD which uses the ILO standard groups 15-64 years of age.

23. Measured as employment divided by the population aged 15-64 years, the government scenario implies an employment rate of 74 per cent in 2050. Both scenarios imply that Roma participation rates converge to assumed averages.

24. Following the period of robust productivity growth rates in the $1950 \mathrm{~s}$ and 1960 s, a pronounced slowdown took place since the early 1970s and notwithstanding the possibility that technological progress has accelerated recently, diminishing catch-up should translate into slower growth over time. See Englander and Gurney (1994). 
Figure 7. Social security deficit: sensitivity to employment and productivity growth Per cent of GDP

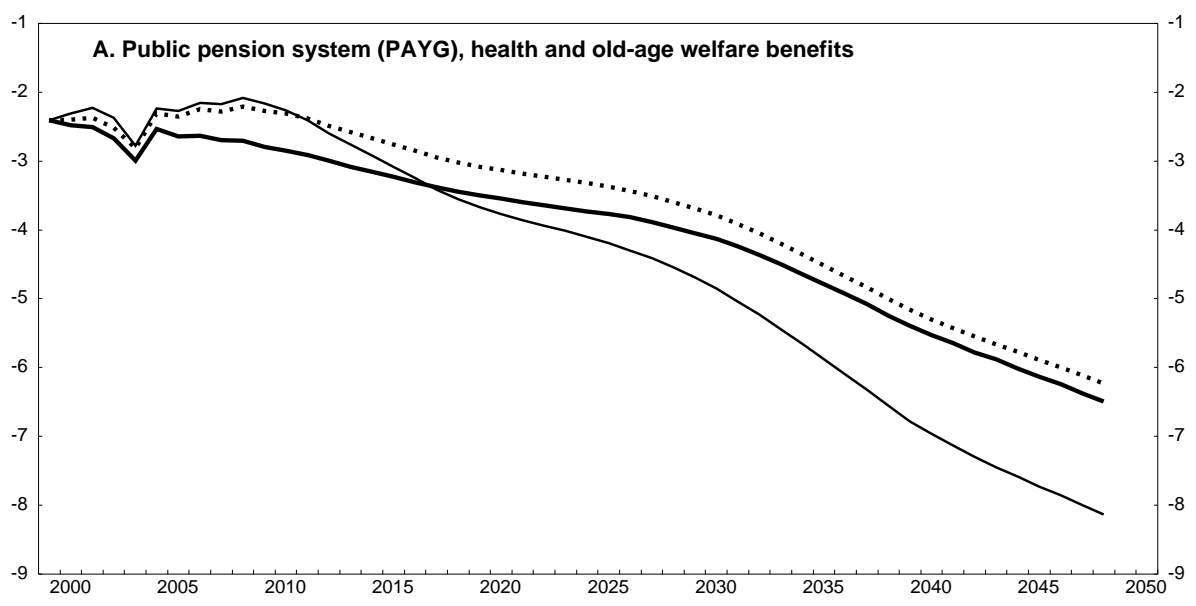

Social security comprises pensions (PAYG), health and old-age/welfare benefits.
Government reference scenario (1)

…... Lower employment (2) Lowario (1)



1. Ministry of Finance model which includes: pension reform completed in 2003; public pension contribution rates remain at 31 per cent until 2050; 2. As in note 1 except for employment which is assumed to rise until 2010 as participation rates converge to the 2010 rates for Austria as estimated by the International Labour Organisation (1997); from 2011-2050, male participation rates remain at the 2010 levels and female rates converge to 90 per cent of the 2010 male rates.
3 . As in note 2 except that productivity grows at a trend rate of 1.75 per cent per year plus 2 per cent of the difference between US and Hungarian levels. Source: OECD; Ministry of Finance. Calculations performed by Hungarian Financial Markets Supervision. 
31. Finally, the overall sustainability of the system will depend on demographic developments. Figure 8 illustrates the sensitivity of results to the young, old and reference scenarios discussed earlier. ${ }^{25}$ Assuming an older population and net out-migration, the overall social security deficit increases by 1 per cent of GDP as compared with the baseline while the higher fertility and immigration of the young scenario translates into about a three quarters of a per cent reduction in the deficit.

Figure 8. Social security deficit: sensitivity to demographic assumptions

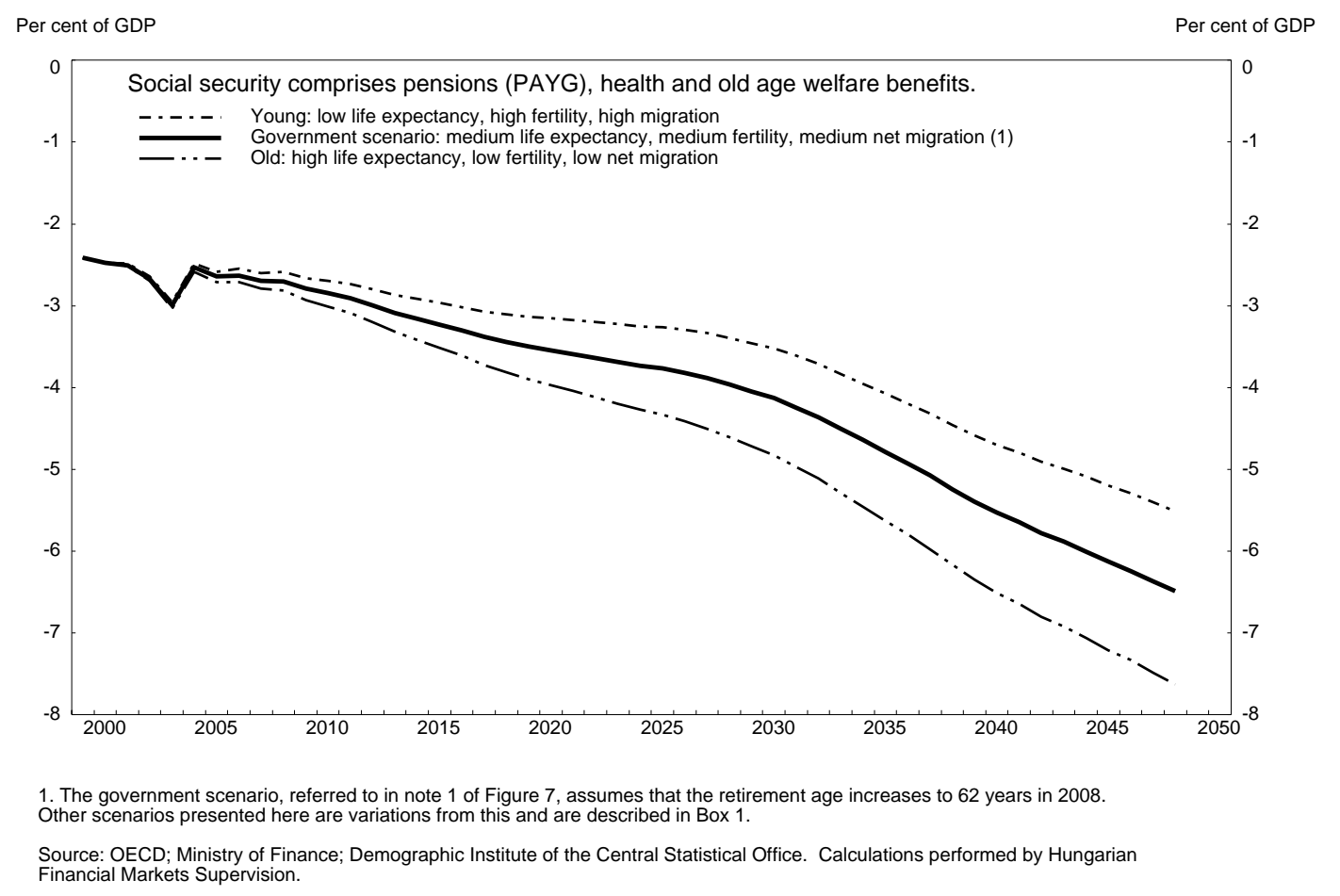

32. As indicated above, the overall viability of the pension system depends, not just upon the PAYG balance, but also the viability of the fully-funded tiers. Rocha and Vittas (2000) estimate that in order to avoid triggering the guarantee, the funds will have to generate a real return of 4.5 per cent annually, assuming 8 per cent contributions, which is much higher than the 2.3 per cent the funds have produced this far. ${ }^{26}$ If shortfalls are large enough to exhaust the Guarantee Fund the government itself will be obliged to provide the Fund with loans that would be sufficient to maintain its liquidity. Evidently the likelihood that a government bailout will be required, increases the longer the inflow to the private funds is kept below the originally agreed 8 per cent. Moreover, the decision to retroactively change the parameters of the private pension scheme undermines the perception of the resulting annuities, which risk being seen as a

25. All three scenarios imply an improvement in fertility and life expectancy over the next 50 years, with the young scenario assuming a relatively higher fertility and lower life expectancy and the old scenario the reverse. In addition, the young scenario assumes net in-migration of 15000 persons per year, while the old scenario assumes annual out-migration of 5000 persons and the reference scenario assumes in-migration of 5000 per annum.

26. The real rate of return was estimated by the OECD on the basis of the financial performance of the mandatory pension funds reported for 1999 by PSzÁF. 
government transfer — subject to political negotiation and pressure tactics - rather a fair return on their savings. The state guarantee of the minimum level of performance of the second-pillar funds was abolished by Parliament in November 2001. Given the retroactive nature of this change in pension reform, it is unlikely that the government would refuse to bail out the Guarantee Fund in case of need.

33. A somewhat less tangible risk associated with the reformed pension scheme concerns its political feasibility. Much of the savings it is to generate derive from steps that reduce the generosity of benefits that it is required to pay out. That reduction is principally achieved by the Swiss indexing formula, which is only partially indexed to wage growth. As a result, over time, the discrepancy between an older pensioner's income and that of a new pensioner will grow, a relative deprivation that could give rise to political pressure for redress. Indeed, already within the Hungarian system some 170000 petitions for reassessment of pensions ( 5 per cent of all pensions) are heard each year and 40-50 per cent of them are granted. In addition, some 4500 claims for one-off social aid are approved by the pension administration each year. Assuming that the average replacement rate were maintained at its current 60 per cent of net earnings rather than declining to 45 per cent as is implicit in the preceding scenarios, OECD projections indicate that (other parameters held constant) the deficit of the public pension system would increase to $23 / 4$ per cent of GDP by 2050 (see the thin line scenario in Figure 9). Furthermore, the higher PAYG payments would risk bringing the Guarantee Fund into play, because the minimum annuity to be paid by the fully-funded system depends (positively) on the level of the PAYG benefits. The government reduced employer's pension contributions by 2 percentage points in 2001 and 2002 respectively. The long-term ramifications of such a change are important. The dotted line in Figure 9 shows the impact of just a 2 percentage point reduction in pension contributions. It shows that in contrast to the baseline scenario, the public pension system would remain in deficit throughout the next 50 years, reaching a maximum of around 1.5 per cent of GDP in the 2050s. If contributions were cut permanently by another 2 percentage points, the pension related revenue shortfall could be expected to rise to about 2.5 per cent of GDP.

\section{Policy priorities}

34. The ageing of the Hungarian population, like that of many OECD countries, appears inevitable. As such, it can be predicted with some confidence and policy makers have the luxury of time to elaborate a response that will deal with challenges it entails in a socially responsible and economically efficient manner. As compared with some OECD countries, Hungary has the additional advantage that the demographic crunch will arrive later and will not be as severe. On the other hand, it has the disadvantage of being a less wealthy society, whose social welfare system already requires high rates of taxation and, thus, there is little scope for expanding old-age related expenditures without making cuts elsewhere.

35. The preceding analysis of demographic trends and their fiscal implications reveals four broad areas where policy clearly needs to concentrate: $i$ ) creation of structures and competencies capable of providing services for a growing elderly population; ii) the fiscal sustainability of the elderly support system; iii) incentives for the optimal use of the population's productive potential; and $i v$ ) the elaboration of a co-ordinated policy framework for dealing with the ageing problem. In the following paragraphs, each of these is discussed in turn. 
$\mathrm{ECO} / \mathrm{WKP}(2002) 24$

Figure 9. PAYG balance with lower contribution rates

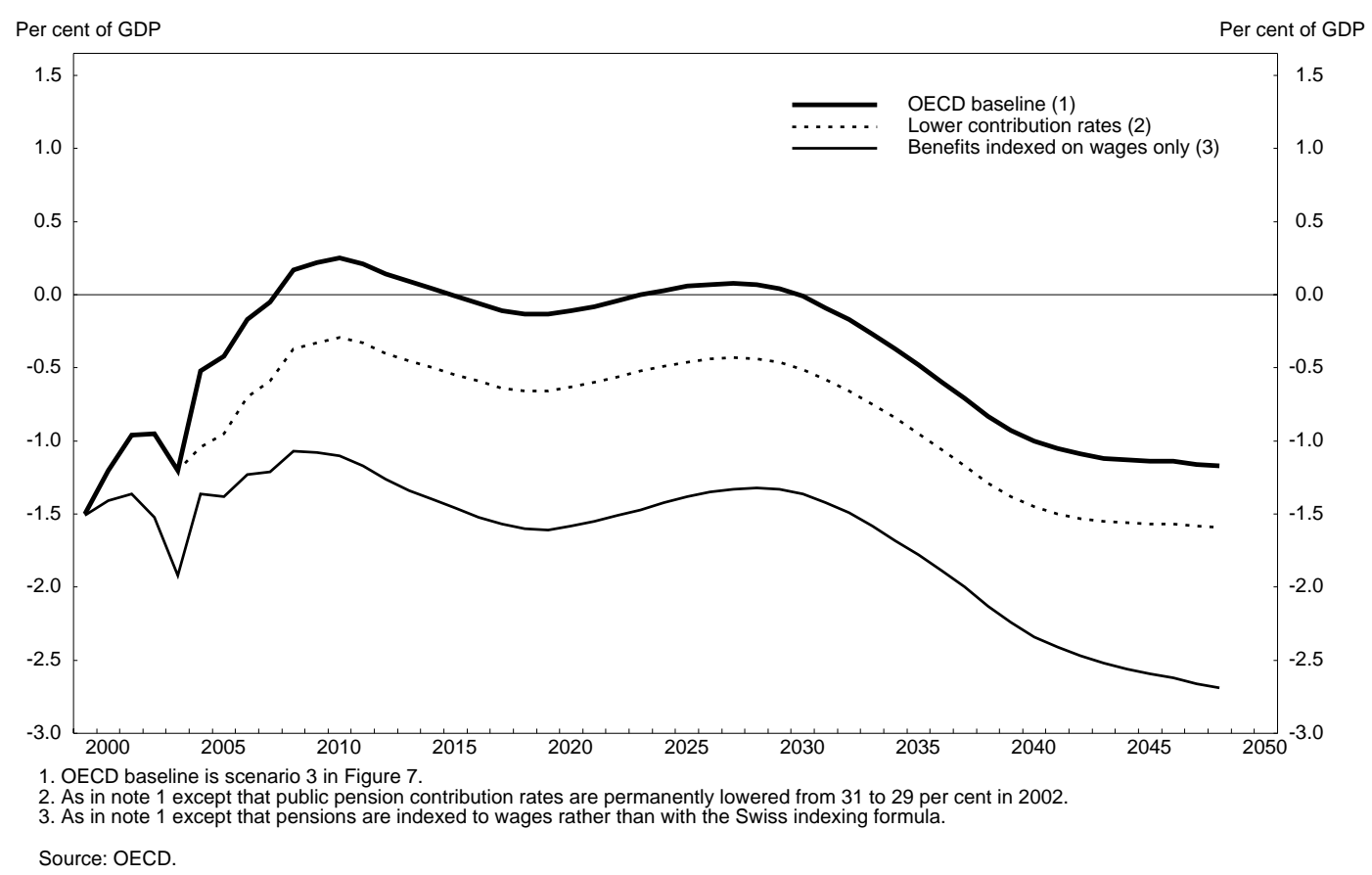

\section{Structures and institutions for the elderly population}

36. The income support structures and specialised service delivery systems in place for the elderly are on the whole adequate for satisfying their needs, except for the provision of long-term care for frail seniors, which is characterised by increasingly long waiting lists. As indicated at length in the previous Economic Survey of Hungary, systemic inefficiencies in the organisation of healthcare delivery in Hungary are currently large and, therefore, there should be ample opportunity for improving the quality of care without increasing expenditures. Those measures most relevant for the elderly population include the creation of more nursing-home spaces, where elderly people in the need of some assistance but not seriously ill can live. Currently too many of these people are receiving the necessary social stimulation and support in high-cost hospital wards, when they could receive a more appropriate and targeted care elsewhere. Here the size of the task is enormous. Hungary is currently the OECD country with the fewest such beds per capita. Just in order to preserve the current number of beds per elderly person, more than 4000 would have to be built, while to raise standards to the OECD average would require almost twice that number. On the other hand, Hungary has the advantage of an extensive system of home-based care which could be built upon to respond to some of the increased demand. Here, however, care will need to be exercised to ensure that mechanisms which evolved during a more rural and solidaristic period of Hungary's history adapt to the changing demands of society. Experience in other OECD countries suggest that as the economy becomes more urban and smaller communities shrink, people will find it increasingly difficult to provide traditional family-based support of the elderly. In such instances, either existing systems will need to be enhanced or more traditional institutions such as nursing homes will have to be 
built and staffed. Moreover, thought needs to be given to how these will fit into the overall medical and social-care systems.

\section{Fiscal consolidation}

37. The fiscal sustainability of the healthcare system is extremely difficult to judge with precision. Nevertheless, it is clear that healthcare expenditures pose the greatest potential threat to the long-term sustainability of the current system, although not all of the problem is ageing related. Indeed, chronic cost overruns have characterised the system in recent years and while budgetary caps on spending categories has kept expenditures under control, they have done little to address the systemic features that have fed the cost overruns. Thus, the current system harbours a substantial quantity of repressed costs in the form of low salaries for doctors and nurses and chronic hospital deficits. As discussed in the special chapter on healthcare in the 1999 Economic Survey of Hungary and in the preceding chapter, much of the problem stems from the hospital-centric nature of the current system and artificial limitations placed both on the National Health Insurance Fund Administration (HIFA) and hospital administrators. Over the long term it will be essential for the HIFA, as the sole purchaser of healthcare services, to be able to enter into selective contracts (which implies the right to refuse contracts with some suppliers) if price competition is to help control costs. Moreover, efforts to expand greatly the range of viable alternatives to high-cost in-patient treatment such as ambulatory care services are required. Over the more immediate term, pharmaceuticals represent the fastest growing component of healthcare costs. While the government's recent decision to freeze their prices will help control their expenditures this year, a longer-term solution is needed. Indeed, it is not at all clear that given Hungary's current level of development whether it can afford as generous a drug subsidisation system as it has. As previously suggested, a long-term solution may well require that the government limit drug support to those most in need, perhaps by restricting subsidies to the young, the old, the chronically ill and those with diseases whose treatment poses a severe financial burden.

38. Despite the substantial scope that exists for improving the quality and efficiency with which care is delivered, the calculations presented in the preceding section suggest that over time demand for healthcare services can be expected to grow substantially. Indeed, the combination of rising aspirations and an ageing population could push demand to as much as 10 per cent of GDP. On the other hand, assuming that the kinds of reforms outlined above are implemented, the system's capacity to supply care can be expected to grow rapidly, although not as quickly as demand. Thus, the gap between what the system is able to deliver, and what people want could grow by as much as 4 per cent of GDP. Under current institutional arrangements, this gap would necessarily show up either as unmet demand (rationing) or an increase in the social security deficit. In addition to reducing the extent to which pharmaceutical expenditures are subsidised, the authorities should consider narrowing the range of healthcare procedures that are provided universally and completely. The solidaristic nature of the Hungarian healthcare system could be preserved while expanding the use of co-payments for inexpensive and common health problems, increasing the role for supplementary private health insurance and reserving significant medical (and pharmaceutical) subsidies for treatments that would represent a serious financial burden for the individual concerned. Assuming that such a policy stance succeeded in holding government spending on the system to about 6 per cent of GDP, rising productivity and GDP would mean that per capita quantity of publicly provided healthcare resources and, presumably, the quality of care would nonetheless increase rapidly (Figure 10). Indeed, service levels would reach the current OECD average level by about 2025 and would be almost 50 per cent higher than that by mid-century. It is clear, therefore, that within the context of the Hungarian health system it will be possible to provide a reasonable level of care at a reasonable cost, although service levels would remain lower than in other OECD countries at that time. The challenge will be to deal with the political but also economic pressures that the rationing of access to the system will generate. 


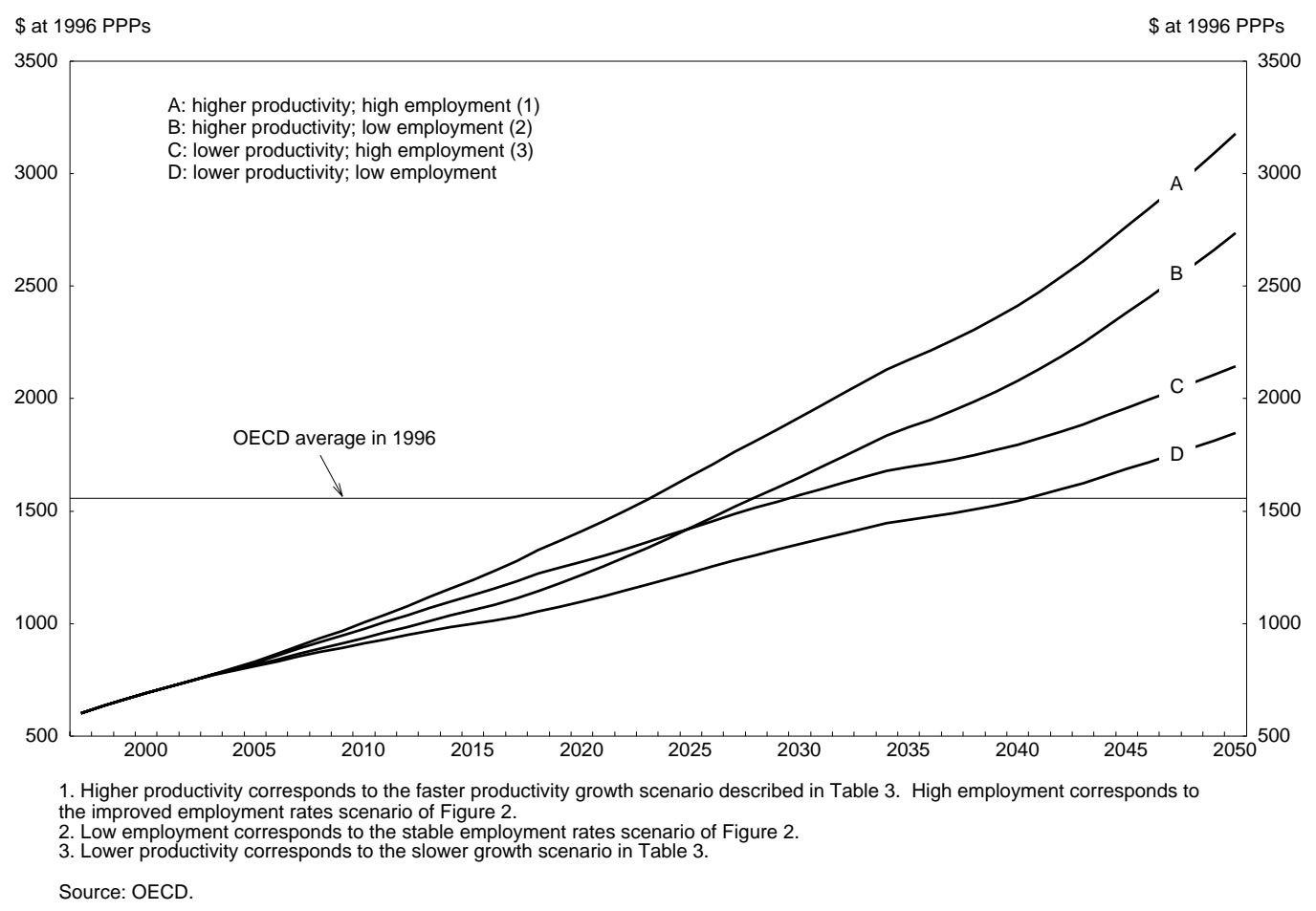

39. As regards pensions, the unexpected popularity of the new regime meant that the deficit of the PAYG system was larger than anticipated, requiring a larger transfer than initially planned from general revenues. ${ }^{27}$ The government responded to the shortfall by holding back at 6 rather than the 8 per cent of gross wages, that part of their obligatory social security contributions, that individuals can place in their private accounts. Instead the government applied the difference to reduce the deficit of the PAYG system (and incidentally that of the general government). Both of these developments could threaten the medium-term sustainability of the second pillar. Currently there are 335000 individuals who are 45 years of age or older that have opted for the new pension scheme. If a substantial portion of them switch back to the full PAYG system before the 31 December 2002 deadline, a number of pension funds could be destabilised. Alternatively, if they remain in the new system then the Guarantee Fund, and ultimately the government budget, could come under significant financial pressure during the period 2013-20 when these workers become eligible for pensions. Moreover, if the government is unable to maintain the lower replacement rates implicit in the reformed PAYG system, the fiscal strain of ageing will be accentuated.

\section{Employment enhancing policies}

40. The ageing of the population and more particularly the shrinking of the labour force have clear economic implications. Fewer employees and slowing productivity growth (as Hungary catches up to the rest of the OECD) mean that GDP (and per capita GDP) will be rising less quickly precisely at the moment when dependency ratios will be rising. In this context, policies that make the most efficient use of available labour supplies — both among older workers (who are currently seriously under-employed) and

27. While it is true that the reformed PAYG (first pillar) pay out is only 74 per cent of the old PAYG benefit, the associated financial savings to the government will start materialising only when the participants in the reformed pension system start retiring in significant numbers after 2015. 
prime-aged ones - will be critical. The following paragraphs attempt to outline some options that might help to reduce the overall dependency ratio, raise productivity growth and thereby reduce the future fiscal burden implied by the ageing of Hungary's population.

41. The current depressed level of employment in Hungary is partly a reflection of the low statutory retirement age and the sharp adjustment the country underwent at the beginning of the transition. However, it is also, to a significant degree, the result of an overt policy decision to reduce labour supply in the face of these shocks by offering a wide-range of early retirement incentives. Recently, the authorities have taken steps to reverse this trend. The decision to abolish some early retirement programmes financed by the Labour Market Fund as of January 1998 was an important step in the right direction, even though the subsequent introduction of a somewhat less generous pre-retirement unemployment benefit tended to have the opposite effect. Nevertheless, the impacts of previous policy continue to be felt, with over 800000 working-age seniors out of the labour force and on some kind of government income support. Bringing these people back into productive life may well be difficult but nonetheless should be seen as a priority. More importantly, every effort should be taken to ensure that the future cohorts of 50-year olds do not follow the previous ones into inactivity but retain their labour force attachments. In this regard and given the strength of the economy and the rapid expansion of employment, the authorities should give serious consideration to completing the withdrawal of early retirement provisions much earlier than 2009, the date at which they are currently envisaging restricting access further.

42. In addition to reducing the importance of early retirement programmes, access to the disability programme, which is an important source of government support for non-employed individuals approaching the retirement age, should be further restricted. A recent tightening of the interpretation of the rules governing access to these benefits was successful in reducing the number of new entrants to the programme. However, the non-employment of as many as 21 per cent of individuals between the age of 50 and 60 years continued to be supported by this programme. Several procedures encouraging a speedier return to work of the temporarily disabled should be considered, including more referrals to vocational rehabilitation programmes provided by the public employment service and the abolition of rules that permit past labour market history and current employment status to be used as criteria for acceding light (Type III) disability pensions. Finally, the provisions for early pensions regulated by the government decree 181/1996 and the so-called miners' pensions should be reviewed and an explicit timetable introduced leading to their eventual abolition.

43. Efforts also need to be made to ensure that work pays for those over the retirement age. Here the tax treatment of pension income and post-retirement earnings can be important. The current treatment of post-pension earnings is reasonable. The earnings of retired workers are taxed at the marginal rate associated with their actual income from employment, while pension benefits themselves are not taxed. Under the new system, to enter into force in 2013, pension revenues will be taxable. Ceteris paribus a working pensioner will be worse off and work incentives reduced after the 2013 because his taxable income will now be based on his gross pension earnings. Work disincentives are especially acute for persons receiving the old age benefit (as opposed to the pension). For such people, the effective tax rate on earned income is 100 per cent an in some case may be higher, ${ }^{28}$ creating a serious poverty trap. Reducing the rate at which these benefits are clawed back would provide recipients with a financial incentive to look for work. More generally, while the structure of the PAYG benefit system does not penalise working beyond the statutory retirement age (62 years as of 2009), ${ }^{29}$ the treatment of older workers by both the

28. The effective tax rate can exceed 100 per cent because earnings results in equivalent benefit withdrawal and are subject to income tax as well, which may or may not be greater than zero.

29. Workers with an accumulated service of at least 38 years can continue working and earn a supplementary entitlement of 0.3 per cent for each month of additional work (providing that they work for at least one year past retirement age). Moreover, such supplementary years are fully pensionable. 
mandatory and the voluntary private funds does create incentive problems. An individual who works beyond the standard retirement age cannot choose to continue contributing to his private savings fund and, therefore, stops benefiting from these schemes' favourable tax treatment. Allowing individuals to participate in their pension funds after the official retirement age and to choose the moment when they transform their savings to an annuity or into a corresponding lump sum (following existing rules) that could be inherited by designated beneficiaries would be more equitable and would improve work incentives.

44. More generally increasing the employability (and productivity) of all workers will help ease the transition to an older population. Here all of the recommendations concerning the labour market made in previous Economic Surveys are relevant. Of particular importance, given the ageing of the working-age population, will be those aimed at improving lifetime learning - so that as the workforce ages its skills evolve with the economy's demands. This will require a radical change in conception of labour market policy, which until recently has focused on helping older workers exit from productive life and income support for younger workers. Moreover, it will be essential to adapt the entire educational system, but especially the vocational system, to recognise that skill acquirement is a lifelong task and a personal responsibility. Here, less emphasis should be placed on defining skill requirements for particular jobs and more time on providing both students and workers with the tools necessary to take full advantage of their innate competencies within a changing environment. In this context, obstacles to part-time work should be reduced so as to increase activity rates in general but also among older workers.

45. A special challenge (and opportunity) is posed by Hungary's Roma (Gypsy) population. Currently this segment of Hungarian society is characterised by low employment rates, acute educational and training deficits, dramatic health problems and a serious problem of exclusion (see Box 4). Depending on the estimate, the Roma represent anywhere from 6 to 9 per cent of Hungarians. ${ }^{30}$ In contrast to the population as a whole, high birth rates among the Roma are predicted to cause their population to double by 2050 , growing to between 13 and 23 per cent of all Hungarians ${ }^{31}$ and according to one estimate their share in the working-age population will rise from 5 to 16 per cent by the middle of the century (Hablicsek, 1999). Currently Romani employment rates are some 50 per cent lower than the average, which could have significant consequences for overall labour supply in the future if they are not better integrated into the labour market (the higher employment scenarios presented above are predicated upon an improvement in Roma integration). Indeed, estimates suggest that raising Romani employment rates to the level of the rest of the Hungarian population would increase GDP growth by 0.2 per cent per annum on average throughout the next 50 years. Here, educational policy, social integration policy and work disincentives stemming from the social security system will need to be carefully examined.

30. CSO data based on self-identification indicate that the Romani population in 1999 was only 143000 or 1.4 per cent of the population, while studies that use the judgement of the surveyor or the evaluation of neighbours place the number closer to 6 per cent (Hablicsek, 1999). Of the two estimates, the latter is considered more accurate by local experts.

31. The lower range is derived from the data provided by the Demographic Institute of the Central Statistical Office of Hungary and based on surveys from the early 1990s; see Hablicsek (1999). According to this source, there are currently some 600000 Roma accounting for 6 per cent of Hungary's population. The highest range of 9 per cent is mentioned in the US State Department 1999 Report on Human Rights Practices in Hungary and close to 8 per cent implied by representatives of the Romani self-government organisations who claim that there are 800000 Roma. The upper estimate is based on the current population share of 9 per cent and the same fertility rates for the Romani population as those identified by the Demographic Institute. 


\section{Box 4. The Romani minority}

Hungarian demographers estimate that some 600000 citizens belong to the Romani (Gypsy) ethnic minority, amounting to 6 per cent of total population. ${ }^{1}$ Other estimates are as high as 9 per cent. ${ }^{2}$ According to the demographic baseline projections consistent with the lower estimate, there will be some 1.2 million Roma living in Hungary by 2050 , accounting for 15 per cent of total population and a slightly higher proportion of the prime working-age population. The labour market participation of Roma has fallen to extremely low levels in the 1990s and welfare dependency has increased correspondingly.

\section{Discrimination}

According to a number of observers, the Roma continue to suffer from discrimination in education, healthcare, policing and the labour market. ${ }^{3}$ The unequal access to health services is reflected in poor health outcomes, including high infant mortality, high incidence of chronic diseases and short life expectancy (10 years below the national average). The minority's educational achievement has been abysmal. A large proportion of Romani schoolchildren are routinely placed into programmes for the mentally handicapped and only 40 per cent complete the first 7 grades of primary school. Only 5 per cent of Romani pupils stay in school until the mandatory age of 16 years and just 1.5 per cent complete the secondary level of education, while virtually none graduate from colleges and universities. In addition, job seekers of Romani origin suffer from overt discrimination with some job advertisements openly discouraging Roma from applying. Generally, the Roma who complete school education or vocational training programmes are twice as likely to become unemployed as the corresponding non-Romani population.

\section{The public response}

Public opinion surveys indicate that a large percentage of the population is resentful of the ethnic minority. Nevertheless, the authorities have started to implement a medium-term programme to improve the living conditions of the Roma. To date, the most successful outcome has been the establishment of ethnic self-government bodies at the local and national levels. This unique institutional innovation, based on a 1993 Act of Hungarian parliament, has helped to integrate an increasing number of Roma communities into the nation's political system, at least tentatively. Their integration into the economic and social mainstream has proved to be much more difficult to achieve, although the authorities have increased the amount of spending on special programmes. Most recently, the government has focussed on reshuffling aid to the Roma, although in April 2000 a new long-term strategy with higher spending commitments was unveiled.

1. See Hablicsek (1999).

2. See US Department of State (2000) and Office for National and Ethnic Minorities (2000). Unlike a number of relatively well integrated minorities, the Roma are classified as Hungary's sole ethnic minority.

3. See OSCE (1998), US Department of State (2000), Office for National and Ethnic Minorities (2000). The official Hungarian source identifies discriminatory practices based on widespread prejudice in these four areas. The first two sources also mention discrimination in housing.

46. In the context of declining employment and rising dependency ratios and, especially given the sensitivity of outcomes to small changes in demographic and behavioural parameters, it would probably be prudent to further increase statutory retirement ages as improvement in life expectancy permits. It is currently scheduled to rise to 62 years for both genders by 2009 . By continuing to raise it gradually to 65 years of age, the deficit of the public pension system would be reduced significantly (Figure 11). Such a reform could be supplemented by increasing labour supply through immigration. Simulations suggest that 
a moderate increase in net inflows ${ }^{32}$ (20000 per year) of working-age immigrants would suffice to maintain employment at its current level and go a long way to stabilising the fiscal balance. While such an inflow, which represents only 0.2 per cent of the population and is well below the rates observed in other OECD countries (including France and Germany), would require a conscious effort on part of the government and society as well as some initial net costs, it would be unlikely to put a strain on Hungarian society. A points-based immigration system could be used to ensure that inflows meet real labour market needs without putting at risk the jobs of ethnic Hungarians. Indeed, a well organised and transparent immigration policy, by proving the country's capacity to manage its borders, would likely serve Hungary well in its negotiations with the European Union.

Figure 11. Sensitivity of the PAYG balance to revenue-enhancing reforms

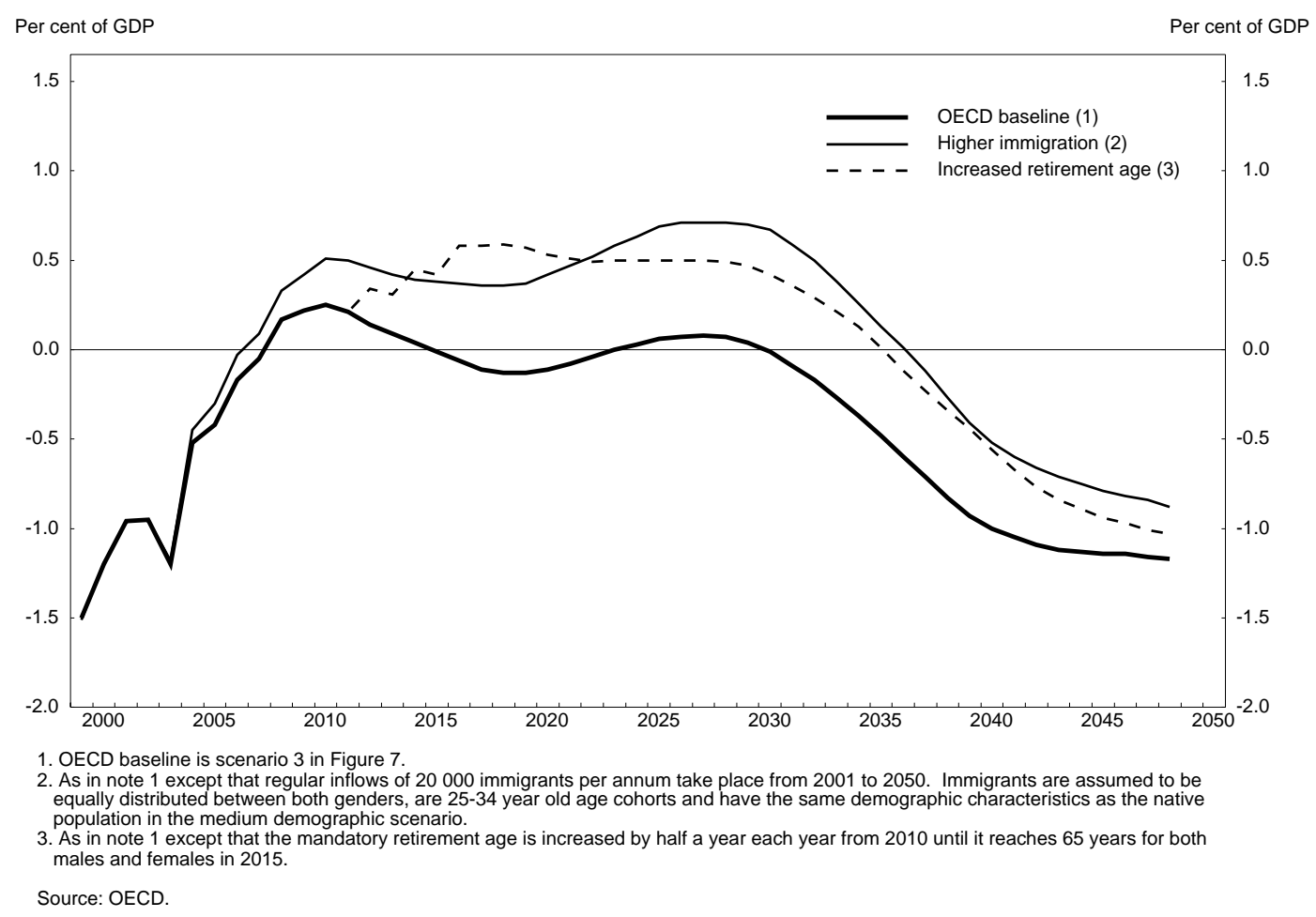

47. These policies could complement ones aimed at promoting higher fertility rates. Recent efforts to reverse the decline in birth rates have failed to stem the fall in fertility and past pro-natal policies in both Hungary and western European have only had transitory effects. Nevertheless, it is possible that a mixture of improving economic prospects and generous benefits could have an impact on family planning decisions. However, it will be critical to examine the potential costs and benefits of such programmes. The recent proposal to offer a tax credit for families with three or more children could, if successful, have a substantial budgetary impact. Furthermore, aside from the serious equity questions raised, the current structure of the proposition, by providing no additional relief to two-child families and virtually total tax relief to those with three or more, would create serious discontinuities and distortions within the tax system. Before implementation a thorough analysis of its potential consequences should be conducted.

32. Limitations associated with the Hungarian Census prevent accurate estimates of the extent of immigration at this time. Thus, this discussion is stated in terms of changes in net inflows. 


\section{Creating a co-ordinated policy framework}

48. The economic policy challenges posed by the ageing of the Hungarian population are significant. While efforts have been made to co-ordinate the response of the Ministries of Health and Family and Social Affairs, a broader effort may be called for. In particular, given the far-reaching implications of the problem and the need to establish a dialogue between citizens, the government and the social partners, it might be useful to set up a formal consultative committee, perhaps in the context of the National Economic Council or the Council of the Elderly and including representatives from academia, business, labour and non-governmental agencies. Ideally, such a group could, by stimulating and informing a public debate, help generate the kind of national consensus necessary to implement difficult decisions in the areas of social security reform, labour and immigration or ethnic minority policies.

49. Accurate statistical information is critical to the policy formation process. Unfortunately, the shortcomings of the available data pertaining to the ageing issues in Hungary are serious, especially in the areas of social, health and long-term care for the elderly. In particular, there is no comprehensive information about the extent of non-cash welfare benefits distributed to low-income seniors by local governments and very limited up-to-date information on the economic and health status of the ethnic minority. While such information deficits should be reduced by the new census completed in 2001, a more frequent updating of the census information related to the ageing issues would ensure that policy makers have a firmer statistical base from which to make decisions. The amount of public expenditure would be relatively small but its lack might result in costly policy errors.

\section{Summing up}

50. Like many OECD countries, the fall of birth rates below the level necessary to sustain the population means that over the next 50 years the population of Hungary is destined to grow older. The problem in Hungary is compounded by relatively low life-expectancy, which means that the overall population will be shrinking at the same time. Indeed, the projected decline in Hungary's population in relative terms - even assuming substantial improvements in natality, life expectancy and immigration is the second largest in the OECD. While the size of the elderly population is projected to double and dependency ratios to rise substantially, the extent of the ageing problem in Hungary is not as important as in other OECD countries - principally because of high mortality rates. Nevertheless, the combination of an ageing and declining population will pose serious economic and social policy challenges over the forthcoming half century. Box 5 summarises the recommendations of this paper.

51. The foregoing analysis indicates that the potential fiscal pressure from the healthcare system poses the most serious risk to public finances in the very long run. To some extent, rising costs of long-term care for the increasing numbers of dependent and frail seniors are inevitable and no obvious candidates for compensating spending cuts can be easily identified. Although the potential for improvements in the efficiency of the public health is far from exhausted, even a vastly more productive system is unlikely to be able to meet the growing demands for medical care unless a somewhat less generous public-sector medical-benefits package, supplemented by private payments for some kind of treatments, can be designed. Indeed, such a system could keep public-sector costs under control while ensuring that the quality of care provided by the state system increases more or less rapidly to current OECD average levels and perhaps, beyond that by the middle of the century. In order for such improvements to be realised, however, it will be imperative that the reform efforts outlined in the last two Economic Surveys of Hungary are carried out. Failing this, the extensive resources already allocated to the healthcare system will continue to be used ineffectively and associated costs risk placing an everincreasing burden on the population. 
$\mathrm{ECO} / \mathrm{WKP}(2002) 24$

\section{Box 5. Increasing prosperity in an ageing society: an overview of recommendations}

\section{Enhancing the fiscal sustainability}

- Raise the statutory retirement age to 65 as life expectancy improves.

- Restore the higher contribution rate to mandatory pension funds.

- Keep eliminating incentives to early retirement in general and unemployment-related light disability pensions in particular.

- Increase the scope for private provision and payment for healthcare services.

- Create more low cost nursing-home spaces to substitute for high-cost in-patient care.

- Pursue reforms to improve the efficiency of the healthcare sector.

\section{Encouraging growth of employment}

- Keep implementing the OECD Jobs Strategy and related recommendations of the previous Economic Surveys.

- Improve the employability of the Romani population, while providing the relevant education, training and public works programmes.

- Reform the pension system to make it actuarially neutral with respect to retirement age.

- Encourage regular inflows of guest workers or immigrants.

- Keep reducing the payroll tax burden while switching to the financing of the healthcare system from general tax revenue.

\section{Create a co-ordinated policy framework}

- Promote awareness of the ageing issue by supporting a public dialogue around reform issues.

- Work to harmonise pension, health and welfare policy initiatives formulated by different government ministries.

- Assure a regular provision of relevant and reliable census data to researchers and policy makers.

52. While the implementation of the previous years' recommendations would go some way to creating a more efficient healthcare delivery system, they contain little in the way of recommendations for shaping the system to deal with future challenges. Indeed, for the moment little research has been conducted to illuminate the special challenges that the ageing of the population will create for the healthcare system. Given the state of the system currently, it is understandable that reform concentrate on solving immediate problems. Nevertheless, future challenges have to be addressed and there is a pressing need for a roadmap for reform that includes a vision of how to respond to the challenge of ageing. The government could develop such a plan by increasing the long-term planning resources of the Ministry of Health; in this regard, the recent creation of the National Institute of Health Improvement (Egészég Fejlesztési Kutató Itézet) is a first step in the right direction.

53. The 1997 pension reform was an important and critical measure to ensure the long-term sustainability of Hungary's income support regime for the elderly. By explicitly recognising the future liability represented by the PAYG system and introducing a multi-pillar scheme with a significant fully-funded component it sought to transfer to the current economically-active generation some of the pension costs that they will generate in the future. The analysis presented in this chapter suggests that, while the future deficit of the pension scheme may be underestimated in official projections, it remains manageable. It is, however, sensitive to a number of parameters. In particular, the decision to keep the contribution rate to the fully-funded system below the originally planned 8 per cent of gross wages could threaten the success of the reform in the near future, if the funds are unable to generate sufficient returns to 
provide retirees with the guaranteed minimum pension. Similarly, plans to reduce employers' contributions will need to be met by tax increases or spending cuts elsewhere if long-term fiscal sustainability is to be preserved. Moreover, the system's long-term balance remains sensitive to the indexing system used. It will, therefore, be necessary to take care if deviations from the current system of calculating benefits are to be considered as these will impact both the balance of the PAYG system but could also threaten the fully-funded scheme. Given that no definitive changes have been made as yet, it would be preferable to find a more transparent solution to the underfunding of the survivor and invalidity pension systems. A better option would be to raise the social security tax rate to be paid by individuals from 1 to 2 per cent, while increasing to 8 per cent of gross wages (as originally planned) the amount that individuals pay into their private funds. This solution would have the advantage of keeping old-age contributions at a level that ensures viability of the second pillar while, when taken in conjunction with the reductions of employers' social security taxes by 4 percentage points over the period 2001-02, would nonetheless allow for considerable reductions in the cost of labour.

54. Perhaps most importantly, the overall sustainability of the system will depend on the capacity of the economy to make full use of its diminishing labour resources. Even in a scenario where employment rates improve considerably to levels well above those in other European OECD countries and productivity levels catch up rapidly, employment levels in Hungary are destined to decline and GDP growth to slow. Here the extensive recommendations already made by the OECD to reduce work disincentives, particularly those concerning the abolition of early-retirement incentives, are very relevant. In addition, the operation of pension systems could be modified so as to eliminate biases that make working after the statutory retirement age less attractive. Although all of these policies will help alleviate the pressures generated by the ageing population, only a substantial improvement in the birth rate, an even higher statutory retirement age or an active policy of immigration can be expected to substantially alleviate long-term pressures and ensure Hungary long-term growth rates in excess of 2 per cent. Of these options, international evidence suggests that increasing immigration rates would be the most effective. While the required additional 20000 net immigrants per year is substantially higher than recent rates, at 0.2 per cent of the population per annum, it is not high in absolute terms. Finally, to help create a social consensus in favour of the kinds of changes necessary to meet the challenges of Hungary's ageing population, it will be necessary to take steps to open an informed and wide-ranging public debate concerning its implications. 
$\mathrm{ECO} / \mathrm{WKP}(2002) 24$

\section{BIBLIOGRAPHY}

ÁPF (1999),

Information about activity of pension funds in the third quarter of 1999, State Private Funds Supervision, Budapest.

Bailliu, J. and H. Reisen (1997),

"Do Funded Pensions Contribute to Higher Aggregate Savings? A Cross-Country Analysis", OECD Development Centre Technical Working Papers, No. 130, December.

Csaba, I. and A. Semjén (1999),

"Welfare Institutions and the Transition: In Search of Efficiency and Equity", in Hungary: Towards a Market Economy, ed. by L. Halpern and C. Wyplosz, Cambridge: CUP.

Englander, A.S. and A. Gurney (1994),

"OECD Productivity Growth: Medium-Term Trends", OECD Economic Studies, No. 22, Spring.

Hablicsek, L. (1999),

A roma népesség demográfiai jellemzöi, kísérleti elöreszámítás 2050-ig, mimeo, Demographic Institute of the Central Statistical Office, Budapest, August.

Hviding, K. and M. Mérette (1998),

"Macroeconomic Effects of Pension Reforms in the Context of Ageing Populations: Overlapping Generations Model Simulations for Seven OECD Countries", OECD Economics Department Working Papers, No. 201.

ILO (1997),

Economically Active Population 1950-2010, ILO, Geneva.

Kamarás, F. (1999),

"Fertility and Economic Surveys of the ECE Region", Standard Country Report, Hungary,

Economic Studies No. 10j, UN ECE, Geneva.

Kestor, E. (2000),

"Drug Groups Attack Budapest", Financial Times, 19 May.

Kohl, R. and P. O'Brien (1998),

"The Macroeconomics of Ageing, Pensions and Savings: A Survey", OECD Economics Department Working Papers, No. 200.

Mahieu, R. (2000),

"Les déterminants des dépenses de santé: une approche macroéconomique", INSEE documents de travail, G2000/01, January. 
Micklewright, J. and K. Steward (2000),

"Child Well-Being in the EU — and Enlargement to the East", Innocenti Working Papers, No. 75, UNICEF Innocenti Research Centre, Florence, Italy.

Ministry of Economic Affairs (2000),

Széchenyi Plan, Budapest, March.

Ministry of Finance (1997),

A Nyugdíjreform háttér információi. Budapest, April.

Murillo, C. et al. (1993),

"Health Care Expenditure and Income in Europe", Health Economics, Vol. 2.

OECD (1997),

Economic Survey of Hungary, OECD, Paris.

OECD (1999a),

Economic Survey of Hungary, OECD, Paris.

OECD (1999b),

Benefit Systems and Work Incentives, OECD, Paris.

Office for National and Ethnic Minorities (2000),

Measures Taken by the State to Promote the Social Integration of Roma Living in Hungary, Ministry of Foreign Affairs, Budapest.

OSCE (1998),

"Public Policies Concerning Sinti and Roma in the OSCE Region", Background paper 4, October.

Parniczky, T. (2000),

"Case Study of the Three-Pillar Pension System in Hungary", OECD Private Pensions Series, Private Pension Systems and Policy Issues, No. 1.

Pecchenino, R. and K.R. Utendorf (1999),

"Social Security, Social Welfare and the Ageing Population", Journal of Population Economics, 12, $607-23$.

Rocha, R. and D. Vittas (2000),

The Hungarian Pension Reform: A Preliminary Assessment, Paper presented at a National Bureau of Economic Research/Kiel Institute of World Economics conference entitled "Coping with the Pension Crisis — Where does Europe Stand?”, Berlin, Germany, 20-21 March.

US State Department (2000),

1999 Country Reports on Human Rights Practices: Hungary, 25 February. 


\section{ECONOMICS DEPARTMENT \\ WORKING PAPERS}

337. Next Steps for Public Spending in New Zealand: The Pursuit of Effectiveness (July 2002) Dave Rae

336. Strengthening the Management of Public Spending in Hungary (July 2002) Jaromir Cekota, Rauf Gonenc and Kwang-Yeol Yoo

335. Automatic Stabilisers and Market Flexibility in EMU: Is There a Trade-Off?

(July 2002) Marco Buti, Carlos Martinez-Mongay, Khalid Sekkat and Paul van den Noord

334. The Economic Consequences of Terrorism

(July 2002) Patrick Lenain, Marcos Bonturi and Vincent Koen

333. Investment in human capital through post-compulsory education and training: Selected efficiency and equity aspects

(July 2002) Sveinbjörn Blöndal, Simon Field and Nathalie Girouard

332. Enhancing the Effectiveness of Public Spending in Switzerland (June 2002) Isabelle Joumard and Claude Giorno

331. Competition and Efficiency in Publicly Funded Services (June 2002) Jens Lundsgaard

330. Policy Pre-Commitment and Institutional Design: A Synthetic Indicator Applied to Currency Boards (May 2002) Marie-Thérèse Camilleri Gilson

329. The Role of Policy and Institutions for Productivity and Firm Dynamics: Evidence from Micro and Industry Data (April 2002) Stefano Scarpetta, Philip Hemmings, Thierry Tressel and Jaejoon Woo

328. Improving the Efficiency and Sustainability of Public Expenditure in the Czech Republic (April 2002) Andrew Burns and Kwang-Yeol Yoo

327. Increases in Business Investment Rates in OECD Countries in the 1990s: How much can be explained by fundamentals?

(April 2002) Florian Pelgrin, Sebastian Schich and Alain de Serres

326. Sectoral Shifts in Europe and the United States: How They Affect Aggregate Labour Shares and the Properties of Wage Equations

(April 2002) Alain de Serres, Stefano Scarpetta and Catherine de la Maisonneuve

325. Coping with Population Ageing in the Netherlands (March 2002) David Carey

324. Public Spending in Italy: Policies to Enhance its Effectiveness (March 2002) Alexandra Bibbee and Alessandro Goglio

323. Overheating in Small Euro Area Economies : Should Fiscal Policy React? (March 2002) Peter Hoeller, Claude Giorno and Christine de la Maisonneuve

322. Encouraging Environmentally Sustainable Growth in Austria (February 2002) Jens Høj and Andreas Wörgötter 


\section{$\mathrm{ECO} / \mathrm{WKP}(2002) 24$}

321. Health Care Reform in Japan (February 2002) Yutaka Imai

320. Enhancing Expenditure Control with a Decentralised Public Sector in Denmark (February 2002) Steen Daugaard

319. Options for Reforming the Finnish Tax System (February 2002) Isabelle Joumard and Wim Suyker

318. Product Market Regulation and Wage Premia in Europe and North America: An Empirical Investigation (January 2002) Sébastien Jean and Giuseppe Nicoletti

317. Competition, Innovation and Productivity Growth: A Review of Theory and Evidence (January 2002) Sanghoon Ahn

316. Labour Market Institutions, Product Market Regulation, and Innovation : Cross Country Evidence (January 2002) Andrea Bassanini and Ekkehard Ernst

315. Ongoing Changes in the Business Cycle - Evidence and Causes (January 2002) Thomas Dalsgaard, Jorgen Elmeskov and Cyn-Young Park

314. Comment encourager une croissance ecologiquement durable en France? (December 2001) Ann Vourc'h et Patrick Lenain

313. Increasing Efficiency and Reducing Complexity in the Tax System in the United States (December 2001) Richard Herd and Chiara Bronchi

312. Product and Labour Markets Interactions in OECD Countries (December 2001) Giuseppe Nicoletti, Andrea Bassanini, Ekkehard Ernst, Sébastien Jean, Paulo Santiago and Paul Swaim

311. Modelling Import Responsiveness for OECD Manufactures Trade (October 2001) Mara Meacci and David Turner

310. Trade Linkages and the Trade Matrices in the OECD Interlink Model (October 2001) Laurence Le Fouler, Wim Suyker and Dave Turner

309. Encouraging Environmentally Sustainable Growth in Australia (October 2001) Ann Vourc'h and Robert Price

308. Financial Market Liberalisation, Wealth and Consumption (September 2001) Laurence Boone, Nathalie Girouard and Isabelle Wanner

307. The Economic Integration of Germany's New Länder (September 2001) Eckhard Wurzel

306. Standard Shocks in the OECD Interlink Model (September 2001) Thomas Dalsgaard, Christophe André and Pete Richardson

305. Fiscal Implications of Ageing: Projections of Age-related Spending (September 2001) Thai Thanh Dang, Pablo Antolin and Howard Oxley

304. The Width of the Intra-European Economic Borders (August 2001) Alain de Serres, Peter Hoeller and Christine de la Maisonneuve 